\title{
Big Tech Acquisitions and the Potential Competition Doctrine: The Case of Facebook
}

\author{
Mark Glick and Catherine Ruetschlin *
}

\author{
Working Paper No. 104
}

October 2019

\begin{abstract}
The Big Tech companies, including Google, Facebook, Amazon, Microsoft and Apple, have individually and collectively engaged in an unprecedented number of acquisitions. When a dominant firm purchases a start-up that could be a future entrant and thereby increase competitive rivalry, it raises a potential competition issue. Unfortunately, the antitrust law of potential competition mergers is ill-equipped to address tech mergers. We contend that the Chicago School's assumptions and policy prescriptions hobbled antitrust law and policy on potential competition mergers. We illustrate this problem with the example of Facebook. Facebook has engaged in 90 completed acquisitions in its short history (documented in the Appendix to this paper). Many antitrust commentators have focused on the Instagram and WhatsApp acquisitions as cases of mergers that have reduced potential competition. We show the impotence of the potential competition doctrine applied to these two acquisitions. We suggest that the remedy for Chicago
\end{abstract}

* Professor and Assistant Professor, Department of Economics, University of Utah.

Email:glick@economics.utah.edu. The authors would like to thank INET for its generous support for this research and Brandi Chase for her research contributions.

https://doi.org/10.36687/inetwp104 
School damage to the potential competition doctrine is a return to an empirically tractable structural approach to potential competition mergers.

JEL Codes: K21, L40, L86.

Keywords: Antitrust Law, Big Tech Companies, Digital Markets, Mergers, Potential Competition Big Tech Acquisitions and the Potential Competition Doctrine: The Case of Facebook 


\section{INTRODUCTION}

The 'Big Tech' companies have all engaged in large numbers of acquisitions of smaller start-ups. Google has acquired 270 companies since 2001.1 Microsoft has made over 100 acquisitions in the last ten years, including acquisitions of Skype, Nokia Devices, LinkedIn and GitHub.2 Amazon has made a similar number of acquisitions including its purchase of Whole Foods.3 Finally, Facebook has acquired 90 companies, mainly start-ups. In the appendix to this paper we list Facebook's acquisitions by year. While many of these mergers could have positive economic benefits, a growing chorus of commentators have argued that they provide a strategic means for dominant firms to solidify and protect their dominance.4 Although this appeared obvious to industry participants, very few of these mergers were investigated or challenged by the antitrust agencies, state attorneys general, or private plaintiffs. We argue that present merger law is illequipped to address the tech firms' acquisition of start-ups when the motive is to insulate themselves from future competitive threats. We contend that the impractical standard of proof under the potential competition doctrine is one of the major obstacles to effective merger control in these markets. In this paper we document Facebook's acquisitions as an example that illustrates our concerns about the ability of current merger law to address acquisitions of small start-ups by dominant tech firms.

The extraordinary levels of proof required by the potential competition doctrine can be traced back to Justice Powell's opinion in United States v. Marine Bancorporation.5 The Marine

1 Tim Wu \& Stuart Thompson, The Roots of Big Tech Run Disturbingly Deep, New York Times, June 7, 2019, https://www.nytimes.com/interactive/2019/06/07/opinion/google-facebook-mergers-acquisitions-antitrust.html. 2 Calls to Rein in the Tech Titans are Getting Louder, The Economist, July 19, 2019.

3 Id.

4 See Tim Wu \& Stuart Thompson, The Roots of Big Tech Run Disturbingly Deep, New York Times, June 7, 2019, https:/www.nytimes.com/interactive/2019/06/07/opinion/google-facebook-mergers-acquisitions-antitrust.html, Elizabeth Warren, Here's How We Can Break Up Big Tech, Medium, March 8, 2019, https://medium.com/@teamwarren/heres-how-we-can-break-up-big-tech-9ad9e0da324c. 5410 U.S. 602 (1974). 
Bancorporation case imposed an unrealistic evidentiary standard for a violation of $\S 7$ of the Clayton Act based on elimination of potential competition, and this standard makes the doctrine inapplicable to today's mergers in digital markets. In what follows, we first describe today's digital markets and the unique issues posed by acquisitions of start-ups by dominant firms. We then trace the history of the potential competition doctrine. Finally, we consider two recent acquisitions by Facebook to illustrate the difficulty of applying the potential competition doctrine to such mergers.

\section{FACEBOOK'S HISTORY OF ACQUISITIONS OF SMALL POTENTIAL COMPETITORS}

Five abnormally large and profitable firms dominate several markets at the center of the digital technology sector. Alphabet/Google, Amazon, Apple, Facebook, and Microsoft are not just the largest firms operating in US digital markets but also among the largest companies in the world, claiming the top 5 spots on the NASDAQ by market capitalization. 6 These five companies are collectively referred to herein as 'Big Tech.' Big Tech firms operate in online platform markets where they provide critical facilitation services between buyers and sellers, users and content providers, and advertisers and consumers.7 Their services include search engines, social networks, ecommerce, digital advertising, app stores, and operating systems, where platforms connect parties online to facilitate transactions. The internet has made platforms exceptionally efficient in

6https://www.nasdaq.com/screening/companies-by-

industry.aspx? exchange=NASDAQ\&sortname=marketcap\&sorttype=1, accessed July 9, 2019.

7 The OECD identifies platforms as the main intermediary between consumers and other digital market participants and distinguishes between attention platforms and matching platforms. OECD, Big Data: Bringing Competition Policy to the Digital Era, November 2016, page 12, https://one.oecd.org/document/DAF/COMP(2016)14/en/pdf. The European Commission offers a definition of online platforms composed of several features: platforms 'share key characteristics including the use of information and communication technologies to facilitate interactions (including commercial transactions) between users, collection and use of data about these interactions, and network effects which make the use of the platforms with most users most valuable to other users.' European Commission, Digital Single Market: Online Platforms, May 2018. Cited in Jason Furman et al., Unlocking Digital Competition: Report of the Digital Competition Expert Panel, HM Treasury Digital Competition Expert Panel, March 2019, page 21 ,

https://assets.publishing.service.gov.uk/government/uploads/system/uploads/attachment_data/file/785547/unlocking _digital_competition_furman_review_web.pdf. 
connecting end users. The tremendous profits earned by these firms create strong incentives for others to enter these markets, yet two or fewer Big Tech firms have dominated many of them for years.8 Some observers contend that the natural process of competitive entry has been diluted by the Big Tech large-scale acquisition programs.9

Online platforms typically operate in two-sided markets including a consumer-facing market for digital services and a market for online advertising. In order for a platform to maintain its position in both the digital services and the online advertising markets, it must maintain the most desirable platform for users and prevent users from switching to other platforms. User traffic is important to both markets because they each exhibit strong network effects. In social networking, for example, users value the social network with the most opportunities to reach others; advertisers benefit from greater user numbers in terms of reach and consumer targeting. Such direct and indirect network effects have resulted in Facebook becoming a dominant provider. Once a dominant firm is established in an online platform market, the network effects and datadriven efficiencies in digital markets tend to reinforce dominance even when improved or novel products are produced by new rivals. 10

8 In June 2019 U.S. Assistant Attorney General Delrahim identified the internet search, social networks, mobile and desktop operating systems, and electronic book markets as controlled by one or two key firms. Makan Delrahim, Assistant Attorney General Makan Delrahim Delivers Remarks for the Antitrust New Frontiers Conference, Department of Justice Office of Public Affairs News, June 11, 2019, https://www.justice.gov/opa/speech/assistantattorney-general-makan-delrahim-delivers-remarks-antitrust-new-frontiers. Fiona Scott Morton et al identify search engines, social networks, network operating systems, ecommerce, and ride-sharing as markets where few firms or one firm hold significant market positions in Fiona Scott Morton et al, Committee for the Study of Digital Platforms Market Structure and Antitrust Subcommittee Report, George J. Stigler Center for the Study of the Economy and the State The University of Chicago Booth School of Business, July 1, 2019, https://research.chicagobooth.edu//media/research/stigler/pdfs/market-structure---report-as-of-24-june-2019.pdf.

9 Tim Wu \& Stuart Thompson, The Roots of Big Tech Run Disturbingly Deep, New York Times, June 7, 2019, https://www.nytimes.com/interactive/2019/06/07/opinion/google-facebook-mergers-acquisitions-antitrust.html. 10 This relationship is characterized by the OECD as a feedback loop in which a company with a large user base can collect more data to improve service quality and acquire new users, generating more user data to mine for monetization opportunities with the resulting funds channeled toward acquiring new users. In this scenario a consumer must choose between a smaller platform with better features but poorer information targeting and the dominant firm with less appealing features but the benefit of data richness. OECD, Big Data: Bringing Competition Policy to the Digital Era, November 2016, page 10, https://one.oecd.org/document/DAF/COMP(2016)14/en/pdf. 
While strong network effects can cause markets to tip and create a dominant firm, they can also allow small nascent competitors with a desirable alternative platform to scale quickly and challenge such dominance. Innovating start-up firms provide competitive pressure in this market when they exhibit rapid user growth and the potential to enter the dominant firm's core market. Prior to entry into the core market, these nascent firms demonstrate their potential by diverting users from the dominant platform or acquiring data that would be valuable on the advertising side of the market. This information provides a signal to the dominant firms which have an incentive to absorb or eliminate them. A nascent competitor can improve the economic performance of the market overall by preventing a dominant firm from reducing quality, raising prices, or curtailing innovation.11 The nascent start-up that blossoms into a competitive rival can reinvigorate the competitive process within the dominant firm's core market. In this context, acquisitions of nascent competitors by dominant firms undermine both current and future competition and reinforce the incumbent's dominance in the face of technological shifts.12

The record of Facebook demonstrates how acquisitions can play a critical role in the rise to dominance and the maintenance of dominance by a Big Tech incumbent. The early history of

11 Jonathan Baker, The Antitrust Paradigm: Restoring a Competitive Economy, 160-161 (2019) ("Future competition may be threatened when a dominant information technology platform (or other large firm) acquires a potential rival. When the potential rival would be expected to innovate were it to enter, possibly leading the dominant incumbent to upgrade its products or services in response, the competitive harms from merger may involve reduced innovation incentives, not just lessened future price competition.")

12 In a recent review of the Industrial Organization empirical literature, Steven Berry, Martin Gaynor, and Fiona Scott Morton describe potential competition as follows. "Acquisition of potential competitors when they are still small can be a way for a dominant firm to improve quality or to fold a complement into its core product-or just to block a future potential entrant. Traditional antitrust enforcement has often focused on whether a merger led to an immediate significant increase in market share, not on how it affected potential or nascent competition. But when a market is subject to strong network effects, competition is for the market, and the possibility that the nascent entrant could contest the incumbent is an important source of competition. Frequently mentioned anecdotes include big tech companies' acquisitions of small firms in adjacent product markets, such as Facebook's acquisitions of Instagram and WhatsApp. In a study of the pharmaceutical industry, Cunningham, Ederer, and Ma (2018) conclude that about 6.4 percent of pharma acquisitions are "killer acquisitions," where the acquisition eliminates entry by a potential competitor. However, both the probability and the value of potential entry are uncertain, and research on identifying or measuring these effects in different settings would be extremely useful." Steven Berry, Martin Gaynor, and Fiona Scott Morton, Do Increasing Markups Matter? Lessons from Empirical Industrial Organization, JOURNAL OF ECONOMIC PERSPECTIVES vol. 33 (3) (Summer 2019) pp. 44-68. 
Facebook is well known. At the time of Facebook's launch in 2004 the social media market was highly competitive, with multiple new social networks emerging each year.13 Facebook's famed beginnings in a Harvard dorm room filled a new niche in the social networking market. The site opened exclusively to the Harvard community-requiring a Harvard.edu email address to joinbefore extending services to Stanford, Columbia, and Yale.14 The interface was simple and provided a few core social networking functions, including profile pages where users could post a single photo and personalized information, as well as a "social graph" or database of connections between individuals that could be searched via user names or other attributes to identify and request new connections. 15

The site was immediately popular and each new user added to its overall utility as more friends or potential friends joined the network. Despite its limited Ivy League user base, by December 2004 the site had grown to one million monthly active members. 16 Its popularity drew the attention of funders which drove expansion, first to more universities, then high schools, then workplaces, and finally in September 2006 to anyone in the world. By the time Facebook was opened to all people willing to register, the company had already received more than $\$ 40$ million in angel and venture capital investments.17 This funding enabled the company to pursue an ambitious growth strategy, including early acquisitions, which made it possible for the company

\footnotetext{
13 Danah M. Boyd \& Nicole B. Ellison, Social Network Sites: Definition, History and Scholarship, 13 Journal of Computer-Mediated Communication 210(2008). Boyd and Ellison provide a timeline of "Major Social Network Sites," showing the launch of six sites in 2003, twelve in 2004, and nine in 2005. 14 Company Info, Newsroom.Fb.Com (May 20, 2019), https://newsroom.fb.com/company-info/. 15 Alan J. Tabak, Hundreds Register for New Facebook Website, The Harvard Crimson, 2004, https://www.thecrimson.com/article/2004/2/9/hundreds-register-for-new-facebook-website/; Alyson Shontell, The Only 8 Features Facebook Had When It Launched in 2004, Business Insider, August 2014, 2014 https://www.businessinsider.com/facebooks-first-8-features-from-2004-2014-8. 16 Company Info, NEWSROOM.FB.COM (May 20, 2019), https://newsroom.fb.com/company-info/. 17 Facebook Funding Rounds, Crunchbase Pro (May 20, 2019) https://www.crunchbase.com/organization/facebook/funding_rounds/funding_rounds_list\#section-funding-rounds.
} 
to take advantage of economies of scale and scope and network effects in the social networking market. 18

Social media use grew rapidly in the years of Facebook's early expansion. According to survey data from the Pew Research Center, just 7 percent of US adults participated in social networking in 2005. Over the following decade, that number would rise to 65 percent, with the fastest growth occurring before 2011.19 Facebook positioned itself to take advantage of this market growth by expanding its user base, articulating a qualitative product differentiation between itself and its competitors, and integrating new ways of engaging users into its suite of social networking functions by offering new features and functionalities.

Facebook operated in a rapidly changing competitive environment where the basic technological undergirding of the social network was evolving, including the increasing importance of mobile technology to connect users online. Beginning in 2007 the company initiated a series of acquisitions of both its potential rivals in the social media market and firms in adjacent markets that could divert user engagement away from the social network. This tactic arguably propelled Facebook's growth strategy as the company overtook its main competitors. Figure 1 shows the number of acquisitions Facebook completed each year from 2004 to 2018, as well as the number of monthly active users reported by the company each year.20

${ }_{18}$ Chris Hughes, It's Time to Break Up Facebook, THE NEW YORK TIMES, May 9, 2019 https://www.nytimes.com/2019/05/09/opinion/sunday/chris-hughes-facebook-zuckerberg.html. 19 Andrew Perrin, Social Networking usage: 2005-2015, Pew Research Center, October 2015 (2015) http://www.pewinternet.org/2015/10/08/2015/Social-Networking-usage-2005-2015/.

20 Acquisitions data from Thomson Reuters Mergers and Acquisitions (M\&A) Data (2019); Nexis Uni Mergers and Acquisitions Data (2019). Number of users reported is monthly active users (MAUs) from corporate reports of Q4 results available at https://investor.fb.com/home/default.aspx and on the corporate information timeline at Company Info, NEWSROOM.FB.COM (May 20, 2019) at https://newsroom.fb.com/company-info/. 


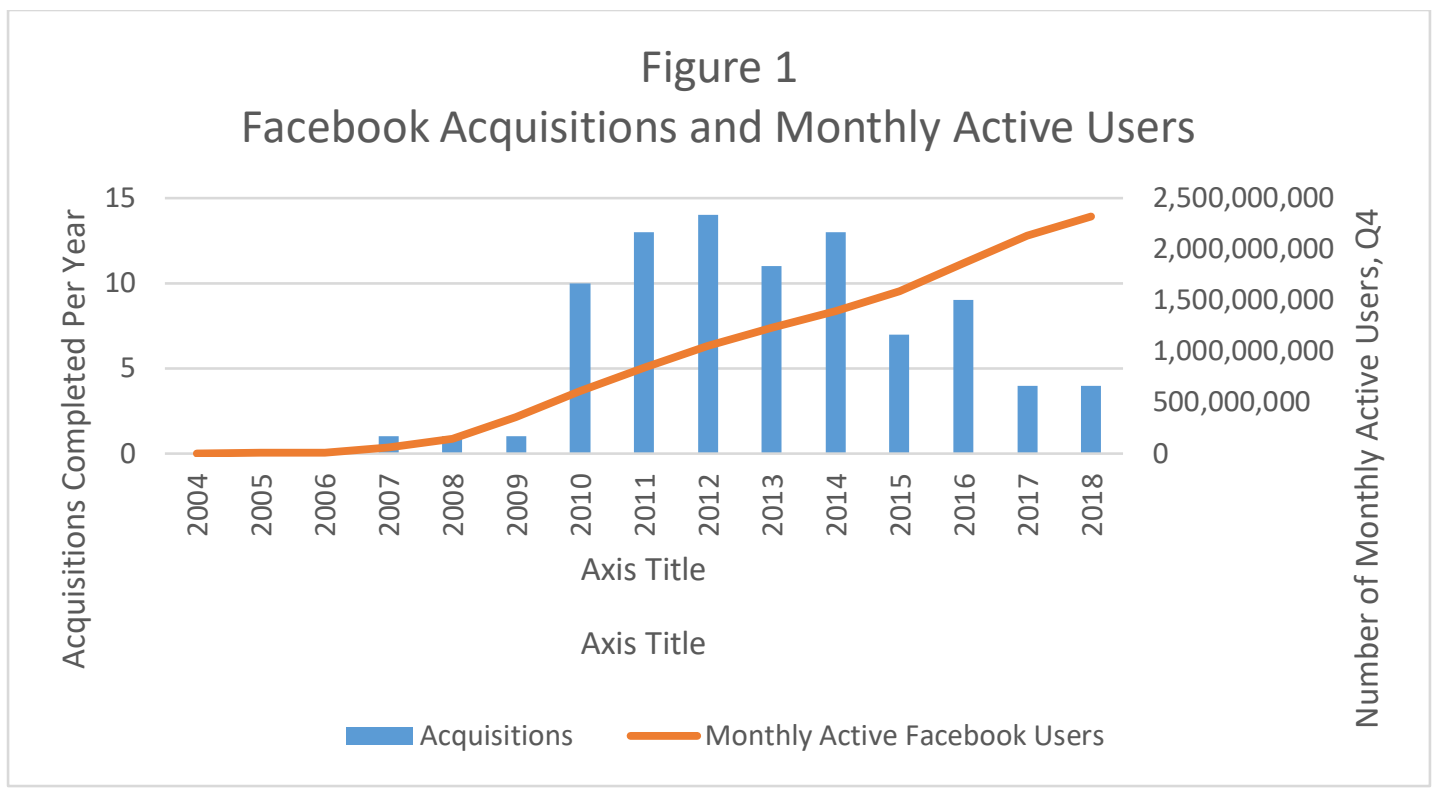

Partially as a result of Facebook's acquisition strategy, when market user growth levelled off competitors like MySpace, Windows Live Spaces, and Google's Orkut suffered significantly, while the number of new users active on Facebook each year continued to measure in the hundreds of millions.21 Facebook first surpassed its main rival, MySpace, to become the most popular website in the U.S. in 2009, just five years after its founding.22 By 2011, when more than half of all adults and two-thirds of internet users were regular users of social networks, Facebook dominated the industry by a wide margin.23 Research from the Pew Research Center in 2011 showed that while 92 percent of social network users regularly accessed Facebook, just 29 percent

21 Erick Schonfeld, Top Social Media Sites of 2008 (Facebook Still Rising), TechCrunch, December 31, 2008, https://techcrunch.com/2008/12/31/top-social-media-sites-of-2008-facebook-still-rising/; Matthew Garrahan, The Rise and Fall of MySpace, THE FINANCIAL TIMES, December 4, 2009 available at https://www.ft.com/content/fd9ffd9c-dee5-11de-adff-00144feab49a; Nicholas Jackson \& Alexis C. Madrigal, The Rise and Fall of MySpace The Atlantic, January 2011, https://www.theatlantic.com/technology/archive/2011/01/the-rise-and-fall-of-myspace/69444/. 22 Chloe Albanesius, More Americans Go to Facebook than Myspace, PC Mag, Jun. 16, 2009, https://www.pcmag.com/news/241432/more-americans-go-to-facebook-than-myspace. 23 Hampton, Keith N., Goulet, Lauren Sessions, Rainie, Lee \& Purcell, Kristen, Social Networking Sites and Our Lives, Pew Research Center, June 2011 (2011) https://www.pewinternet.org/wpcontent/uploads/sites/9/media/Files/Reports/2011/PIP-Social-networking-sites-and-our-lives.pdf. 
utilized the nearest competitor, MySpace, while 18 percent used LinkedIn and 13 percent used Twitter.24

From 2007 to 2018 Facebook acquired or attempted to acquire more than 100 companies in competing and adjacent markets. The 90 acquisitions completed since the company's founding, and documented in the Appendix, range from small acquisitions like the $\$ 2.5$ million purchase of location services network Nextstop to the $\$ 19$ billion acquisition of popular instant messaging rival WhatsApp in 2014.25 They include deals that transferred key technology and expertise to the company in markets for app development platforms, instant messaging, photo sharing, location services, user information and surveillance, and advertising and analytics. Many of the acquisitions converted stand-alone apps, websites, and platforms that worked interoperably across competing networks into Facebook-exclusive features. Other products were simply shuttered in the days or months following their acquisition. 26

\footnotetext{
$24 I d$.

25 https://newsroom.fb.com/news/2014/02/facebook-to-acquire-whatsapp/.

${ }_{26}$ For example, in 2010 Facebook absorbed and closed Divvyshot, a photo sharing service with functions integrated across Flickr, Twitter, and Facebook. Divvyshot's staff transitioned to work on Facebook Photos. In May 2011, after the announcement of the Instagram acquisition, Facebook acquired and closed Lightbox, an Android-native social photo app that was perceived as an "Instagram killer" before Instagram's Android launch. More recently, Facebook purchased the popular social polling application for teens tbh. Facebook allowed tbh to operate under its own brand name for 8 months before terminating the app due to low usage. Erick Schonfeld, Facebook Buys Up Divvyshot to Make Facebook Photos Even Better, TechCrunch, April 2, 2010, https://techcrunch.com/2010/04/02/facebook-buysup-divvyshot-to-make-facebook-photos-even-better/. Josh Constine, Facebook Hires Team From Android Photosharing App Dev Lightbox To Quiet Mobile Fears, TechCrunch, May 15, 2012, available at https://techcrunch.com/2012/05/15/facebook-lightbox/. Emil Protalinski, Facebook Acquires Mobile Photo Sharing Startup Lightbox, ZDNet, May 15, 2012, https://www.zdnet.com/article/facebook-acquires-mobile-photo-sharingstartup-lightbox/. Naina Khedekar, Interview with Stephen Robert Morse from Lightbox, Firstpost Jan. 18, 2012, https://www.firstpost.com/tech/news-analysis/interview-with-stephen-robert-morse-from-lightbox-3593563.html. Josh Constine, Facebook Acquires Anonymous Teen Compliment App tbh, Will Let it Run, TechCrunch, October 16, 2017, https://techcrunch.com/2017/10/16/facebook-acquires-anonymous-teen-compliment-app-tbh-will-let-itrun/. Jacob Kastrenakes, Facebook is Shutting Down a Teen App it Bought Eight Months Ago, The Verge, July 2, 2018, https://www.theverge.com/2018/7/2/17528896/facebook-tbh-moves-hello-shut-down-low-usage. Ingrid Lunden, Facebook is shutting down Hello, Moves and the anonymous teen app tbh due to 'low usage', TechCrunch, July 2, 2018, https://techcrunch.com/2018/07/02/facebook-is-shutting-down-hello-moves-and-the-anonymous-teenapp-tbh-due-to-low-usage/.
} 
Today, Facebook is number three on the list of most-trafficked websites in the world.27 With Instagram, Messenger, Facebook, and WhatsApp, the company now owns four of the most popular mobile apps in the US.28 Facebook is responsible for about 10 percent of the mobile browser market, representing a substantial share of mobile users for whom Facebook is the main point of entry for online content.29 This remarkable influence over how individuals engage and consume online is the product of over a decade of strategic internal growth, as well as the acquisition of potential competitors and the integration of their user traffic and functionality within the Facebook structure.

Remarkably, Facebook's ascendancy in concert with its numerous acquisitions stimulated little interest by the antitrust agencies. A march to dominance, accompanied by numerous acquisitions of potential competitors, puts Facebook's strategy directly within the merger regulatory power of the government through its ability to enforce $\S 7$ of the Clayton Act. Yet few of the acquisitions faced review from antitrust authorities in the U.S. In 2012 the FTC conducted a nonpublic investigation of the $\$ 1$ billion Facebook-Instagram merger and did not recommend any further action.30 In 2014 U.S. regulators cleared Facebook's \$19 billion acquisition of the messaging application WhatsApp, though the FTC did send both companies a letter reminding

27 Alexa Top Sites accessed May 22, 2019 available at https://www.alexa.com/topsites. 28 Max Zahn, Facebook Owns 4 of the Top 5 Most Downloaded Apps, Yahoo Finance July 25, 2019, https://finance.yahoo.com/news/facebook-messenger-whatsapp-instagram-125929036.html. Apple Presents the Best of $2018 \mathrm{https}: / / \mathrm{www}$. apple.com/newsroom/2018/12/apple-presents-the-best-of-2018/; iTunes Charts accessed May 22, 2019 https://www.apple.com/itunes/charts/free-apps/; Microsoft Most Popular Apps accessed May 22, 2019 https://www.microsoft.com/en-us/store/most-popular/apps/pc. 29 Sarah Perez, Facebook is Now a Major Browser in U.S., with 10\%+ Market Share in Many States, TECHCRUNCH, August 6, 2018, https://techcrunch.com/2018/08/06/facebook-is-now-a-major-mobile-browser-inu-s-with-10-market-share-in-many-states/.

30 FTC, Closing Letter to Counsel for Facebook, Inc, August 22, 2012, https://www.ftc.gov/sites/default/files/documents/closing_letters/facebook-inc./instagraminc./120822barnettfacebookcltr.pdf. 
them of their obligation to maintain privacy practices in accordance with the WhatsApp user agreement in place at the time that user data was collected.31

Unlike many other companies acquired by Facebook, Instagram and WhatsApp remained separate from Facebook's social network in branding until 2019, and in some features of interoperability and data autonomy. They are also globally important market leaders in social networking, photo sharing, and instant messaging. The scale, innovation, and popularity of these products have made them frequent examples of potential competitors both at the times of the acquisitions and in the years since. So why have authorities demonstrated reluctance to seriously confront the competitive impact of these and similar mergers among high tech companies? We argue below that the potential competition doctrine, as developed during the years of the influence of the Chicago School of antitrust, has played an important role in insulating acquisitions of startups by the dominant tech companies from the levels of antitrust scrutiny necessary to protect consumers and the competitive process in technology markets.

\section{THE POTENTIAL COMPETITION DOCTRINE}

Facebook and other Big Tech companies maintain their market dominance by harnessing the network effects that reinforce user value in the consumer-facing market and advertiser benefits in digital advertising markets. Innovative start-up firms provide competitive pressure in these markets despite the tendency toward tipping when small firms exist that have the potential to rapidly siphon off users to more desirable or innovative platforms, collect valuable data on end users, or both. In this context, the acquisition of start-up companies may benefit the dominant firm by reducing the disciplining competitive pressure of potential entrants on the periphery of the

${ }_{31}$ FTC, Letter From Jessica L. Rich, Director of the Federal Trade Commission Bureau of Consumer Protection, to Erin Egan, Chief Privacy Officer, Facebook, and to Anne Hoge, General Counsel, WhatsApp Inc., April 10, 2014, https://www.ftc.gov/system/files/documents/public_statements/297701/140410facebookwhatappltr.pdf. 
market or by preventing future entry and expansion by such firms that could undermine the incumbent's dominance. Under the antitrust laws, an acquisition of a potential entrant is analyzed under the potential competition doctrine. Thus, to understand the ability and potential to regulate acquisitions by dominant tech firms it is important to understand how the law of potential competition mergers developed and why it has been so underutilized to date.

The history of the potential competition doctrine informs the analysis of tech industry acquisitions because it demonstrates how a shift in the standard of analysis beginning in the 1960s and culminating in the 1974 United States v. Marine Bancorporation decision undermined the applicability of the doctrine in a range of contexts including online platform markets. The potential competition doctrine emerged in the aftermath of the 1950 Amendment to $\S 7$ of the Clayton Act.32 As described by the Supreme Court in Brown Shoe v. United States, the "dominant theme pervading congressional consideration of the 1950 amendments was a fear of what was considered to be a rising tide of economic concentration in the American economy."33 In 1963, the Supreme Court, in United States v. Philadelphia National Bank, explained that the "intense congressional concern" about increasing concentration "warrants dispensing, in certain cases, with elaborate proof of market structure, market behavior or probable anticompetitive effects." 34

Under this standard, expectations of the market-disciplining effects of potential competition operated to preserve competition in cases where the doctrine applied. The Court explained that when there is a structural increase in concentration due to a merger, the merger "is so inherently likely to lessen competition substantially that it must be enjoined in the absence of evidence clearly showing that the merger is not likely to have such anticompetitive effects." 35

32 The Celler-Kefauver Act, 64 Stat. 1125.

33 Brown Shoe v. United States, 370 U.S. 294, 315 (1961).

34 United States v. Philadelphia National Bank, 374 U.S. 321, 363 (1963).

${ }_{35} I d$. 
Thus, the Court created a presumption of an anticompetitive effect from a structural increase in concentration, and it placed the burden on the merging parties to refute the presumption. The plaintiff must still define the relevant markets involved and measure market shares and concentration, but a full-blown analysis of the impact of the merger was judged by the Court to be unrealistic and counter to the Congressional intent to stem the rising levels of concentration in the United States.36

The Court's approach is often referred to as a "structural approach" which is shorthand for the belief that mergers above a certain concentration threshold have a reasonable probability of harming competition.37 The structural approach to merger analysis contrasts to the effects-based approach, which requires a prediction of the future competitive effects of the merger by use of detailed economic analysis. The Philadelphia Bank opinion implicitly rejected the effects-based approach because of its intractability.38 As the Eighth Circuit later commented, the structural approach is preferable in cases concerning potential competition since "proof of liability under either [potential competition] theory is certain to entail expensive, uncertain litigation, even if, as here, the acquiring firm is rich and powerful and the acquired firm's market highly concentrated." 39 The practical requirements of proving the competitive effects of the threat of entry were deemed nearly insurmountable despite the importance of these effects.

In contrast to the Philadelphia Bank paradigm, later Supreme Court cases developed an unworkable legal standard for the potential competition doctrine. The Court imposed an initial stage open-ended proof requirement involving prediction of future conduct and performance that

\footnotetext{
36 Today the analysis of a relevant market can involve sophisticated economic techniques and analysis of data. Jonathan Baker, Market Definition: An analytical Overview, 74 Antitrust Law J. 129 (2007).

37 Jonathan Baker refers to this approach as "truncated condemnation." Jonathan Baker, The Antitrust Paradigm: Restoring a Competitive Economy 142 (2019) ("Condemnation is described as truncated because it does not require a comprehensive analysis of the nature, history, purpose, and actual or probable effect of the practice evaluated"). 38 Joseph Brodley, Potential Competition Mergers: A Structural Synthesis, 87 Yale L. J. 1, 8-9 (1977).

${ }_{39}$ Ginsburg v. INBEV NV/SA, 623 F.3d 1229, 1234 (8th Cir. 2010).
} 
could not be practically discharged. In developing this standard the Court divided potential competition into two separate legal doctrines--the actual potential competition doctrine and the perceived potential competition doctrine--with distinct evidentiary requirements. Perceived potential competition referred to the pre-entry competitive restraint of the potential entrant, and actual potential competition denoted the future increase in rivalry from the entry itself. After separating actual and perceived potential competition the Court twice expressed doubt regarding the viability of the actual potential competition doctrine. In these cases, the Court discussed the actual potential competition doctrine primarily in the context of acquisitions targeting a dominant firm, and not the context relevant to the current Big Tech mergers in which a dominant firm targets a start-up.

The Supreme Court first addressed the issue of harm to future potential competition from a merger one year after the Philadelphia Bank decision in United States v. El Paso Natural Gas Co.40 This case provides important insights for the viability of the potential competition doctrine to Big Tech mergers, since it is the chief example of the doctrine applied to a case where the potential entrant is the target firm. The case involved the merger between two natural gas pipeline companies and their impact on the California market. El Paso Natural Gas was the only supplier of natural gas to California when it attempted to acquire Pacific Northwest. The Court noted that Pacific Northwest had attempted to enter the California market by supplying Canadian natural gas to one of El Paso's customers in Southern California, Southern California Edison Co. The deal fell through only when El Paso agreed to a more favorable contract with its customer. The Court conceived of the potential harm from the merger as the elimination of influence of the potential entrant on El Paso, or the perceived potential competitive impact of Pacific Northwest. As the

40 United States v. El Paso Natural Gas Co., 376 U.S. 651(1964). 
Court stated, "[w]e would have to wear blinders not to see that the mere efforts of Pacific Northwest to get into the California market, though unsuccessful, had a powerful influence on El Paso's business attitudes within the State." 41 Pacific Northwest's threat of entry forced El Paso to act competitively despite the company's monopoly in the California market. The evidence showed that El Paso did prevent Pacific Northwest's entry by matching and exceeding Pacific Northwest's offer to a California customer. If Pacific Northwest had captured the customer it would have entered. Nevertheless, the Court chose to focus on the current impact of the entry attempt on El Paso's bid, rather than the more significant future impact Pacific Northwest might have had had it become a competitor in the California market. The Supreme Court would follow this emphasis on the impact of perceived potential competition in subsequent cases.

In the same year, the Supreme Court issued an opinion in another potential competition case. In United States v. Penn-Olin Chemical Co, the Court appeared to reject the structural approach of Philadelphia Bank, defaulting to a vague, opened ended analysis. United States $v$. Penn-Olin Chemical Co involved a joint venture rather than a merger.42 All joint ventures raise potential competition issues because absent the joint venture one or both of the same companies might enter into the market alone. In the Court's analysis, the joint venture eliminated a perceived potential entrant, removing the impact of an "aggressive, well-equipped and well-financed corporation engaged in the same or related lines of commerce waiting anxiously to enter an oligopolistic market" which disciplined the existing competitors. Citing the El Paso Natural Gas case, the Court stated that potential competition "is not susceptible of a ready and precise answer." It stated that analysis of the impact of a potential entrant depends on "the nature or extent of that market and by the nearness of the absorbed company to it, that company's eagerness to enter that

41376 U.S. at 659.

42 United States v. Penn-Olin Chemical Co, 378 U.S. 158 (1964). 
market, its resourcefulness, and so on." 43 In Philadelphia Bank the Court had addressed the comparable complications of predicting the future effects of a horizontal merger by establishing structural judicial guidelines. Now, when addressing a parallel prediction of the impact of a potential competitor, the Court surprisingly defaulted to an ambiguous and open-ended narrative. The Court might be forgiven because it resolved the controversy by remanding the case back to the lower court to consider the perceived potential competition impact of the joint venture, but it did so without clear guidance on how such an analysis should proceed. In so doing the case set a precedent in which the structural approach to potential competition was set aside in favor of a range of claims and presumptions about the intentions and perceptions of merging firms.

In 1967, the Supreme Court again confronted a potential competition problem in Federal Trade Commission v. Procter \& Gamble Co,44 and moved the doctrine closer to the unworkable effects-based approach deduced from a subjective and imprecise evaluation of competitive conditions. Following the acquisition of Clorox Chemical Co. by Procter \& Gamble Co., the FTC Commission blocked the merger, asserting, among other reasons, that Procter \& Gamble was likely to enter the bleach market absent the acquisition. Proctor and Gamble was a potential competitor in the market and had already launched an abrasive cleaner that was a differentiated substitute for liquid bleach. Procter \& Gamble knew the liquid cleaning business, the customers of Clorox and Procter \& Gamble largely overlapped, and the company advertised and merchandised in the same manner as Clorox. All of the factors led the FTC to conclude that the acquisition of Clorox by Procter \& Gamble would eliminate a likely entrant into the liquid bleach market. Yet the Court of Appeals rejected the evidence of the closeness and proximity of the two markets and declared that there was insufficient evidence from the management of Proctor \& Gamble that it intended to enter 
the liquid bleach market. The Supreme Court reversed the Court of Appeals but without offering a helpful analysis of the potential competition issues. The Court abstained from analysis of actual potential competition and focused solely on the impact of Proctor \& Gamble as a restraining perceived potential competitor, even though the Court opined that it was "the most likely entrant" into the liquid bleach market. The Court also found, without explaining its basis, that Procter $\&$ Gamble did not face a barrier to entry and that "the number of potential entrants was not so large that the elimination of one would be insignificant." 45 The focus of the Court of Appeals and the Supreme Court on aspects of competition such as the potential competitor's intention of entry, the likelihood of entry, and the number of potential entrants would support the inclusion of such difficult and even subjective or illusory criteria in the evidentiary standards for potential competition cases.

In 1968, the Department of Justice issued Merger Guidelines. While the Supreme Court was grappling with the early cases involving mergers that harm competition by preventing future entry, the Department of Justice developed a clear policy to protect new entry from mergers by dominant firms. According to the 1968 Merger Guidelines:

"Since potential competition (i.e., the threat of entry, either through internal expansion or through acquisition and expansion of a small firm, by firms not already or only marginally in the market) may often be the most significant competitive limitation on the exercise of market power by leading firms, as well as the most likely source of additional actual competition, the Department will ordinarily challenge any merger between one of the most likely entrants in the market" and a firm with a large share of the relevant market.46

The acquiring or target firm must be one with the ability and incentive to enter and must be "one of the most likely potential entrants in the market." As discussed in a later section of this paper,

45386 U.S. at 581.

461968 Merger Guidelines at $\S 18$. 
the 1968 Guidelines faltered when addressing the evidentiary burden required to show that a target is one of the most likely potential entrants. According to the 1968 Guidelines:

In determining whether a firm is one of the most likely potential entrants into a market, the Department accords primary significance to the firm's capability of entering on a competitively significant scale relative to the capability of other firms (i.e., the technological and financial resources available to it) and to the firm's economic incentive to enter (evidenced by, for example, the general attractiveness of the market in terms of risk and profit; or any special relationship of the firm to the market; or the firm's manifested interest in entry; or the natural expansion pattern of the firm; or the like). 47

The 1968 Merger Guidelines’ explanation of the required evidence to demonstrate potential entry is not a model of clarity. It requires that the Department of Justice marshal evidence demonstrating that entry by the firm would be more profitable and less risky than other unidentified non-litigant third-party firms. In 1984 the Department of Justice would give more structure to this inquiry but would continue to require unworkable conduct and performance evidence that would make the potential competition analysis impractical and infrequent.

More clarity emerged from the Supreme Court's 1973 opinion in United States v. Falstaff Brewing Corp. 48 The case involved the acquisition of Narragansett Brewing by Falstaff. Narragansett produced beer sold in the New England regional geographic market. Falstaff sold beer in 32 states and was the largest beer producer not in the New England market. The trial at the District Court considered both the theory that Falstaff disciplined competition as a potential entrant and that Falstaff was a future actual entrant into New England. The District Court held that evidence from Falstaff's management cast doubt on whether Falstaff was going to enter the New England market and that competition had not decreased since the consummated acquisition. Again, despite acknowledging the pertinence of the actual potential competition doctrine, in their decision 
the Supreme Court focused solely the perceived potential competition aspect of the situation in which the merger "eliminates a potential competitor exercising present influence on the market." 49 The opinion stated that the District Court erred by assuming that the subjective evidence from Falstaff's management meant that, as a matter of fact, Falstaff was not a potential entrant. Instead, the District Court should have considered the objective evidence. According to the Court:

\begin{abstract}
"The specific question with respect to this phase of the case is not what Falstaff's internal company decisions were but whether, given its financial capabilities and conditions in the New England market, it would be reasonable to consider it a potential entrant into that market...The District Court should therefore have appraised the economic facts about Falstaff and the New England market in order to determine whether in any realistic sense Falstaff could be said to be a potential competitor on the fringe of the market with likely influence on existing competition." 50
\end{abstract}

If the District Court's approach had prevailed, it would have meant that plaintiffs asserting potential competition cases could be defeated by the uncontroverted testimony of the management of one of the merging entities.51 Instead the Court thought that the proper inquiry was whether a rational incumbent firm would have perceived the acquirer as a likely entrant. It stated that "if it would appear to rational beer merchants in New England that Falstaff might well build a new brewery to supply the northeastern market then its entry by merger becomes suspect under $§ 7 . " 52$ However, the Court does not inform us concerning what "economic facts about Falstaff and the New England market" should have been analyzed, or what objective evidence should be consulted in order to ascertain the beliefs of a rational beer merchant. It appears that a complex, open-ended inquiry of this nature would lead to an unmanageable problem for a Court. For an actual potential

\footnotetext{
49410 U.S. at 532.

50410 U.S. at 533-534.

51 This lesson would be overlooked by subsequent lower court opinions discussed below.

52410 U.S. at 533.
} 
competition case the Court offered even less, declining to even hold that a merger that prevents actual entry violates $\S 7$ of the Clayton Act:

"We leave for another day the question of the applicability of $\S 7$ to a merger that will leave competition in the marketplace exactly as it was, neither hurt nor helped, and that is challengeable under $\S 7$ only on grounds that the company could, but did not, enter de novo or through "toe-hold" acquisition and that there is less competition than there would have been had entry been in such a manner." 53

The Court's reluctance is puzzling. As described by Joe Brodley, the Court has ample scope to apply and interpret the actual potential competition doctrine in both law and precedent. In early Supreme Court cases, the Sherman Act has been held to cover actual potential competition,54 and the Clayton Act "is an incipiency statute designed to prevent [mergers] that are beyond the scope of the Sherman Act." 55

The last and most influential Supreme Court case addressing the potential competition doctrine is United States v. Marine Bancorporation.56 The 1974 opinion, penned by Justice Powell, established the extraordinarily high requirements of proof that inoculate potentially anticompetitive mergers from scrutiny under the potential competition doctrine today. The case concerned the acquisition by Marine Bancorporation, a large Seattle-based bank, of the Washington Trust Bank, a smaller bank headquartered in Spokane, Washington. The government challenged the merger on both perceived and actual potential competition grounds. It argued that Marine Bancorporation's presence on the fringe of the Spokane market disciplined Spokane competitors, and that absent the merger, Marine would likely enter the Spokane market.

53410 U.S. at 537.

54 E.g., American Tobacco Co. v. United States, 328 U.S. 781,809 (1946); United States v. Trenton Potteries Co., 273 U.S. 392, 397 (1927).

55 Joe Brodley, Potential Competition under the Merger Guidelines, 71 Calif. L. Rev. 376, 381 (1983).

56418 U.S. 602 (1974). 
The District Court found against the Government because Washington's state banking regulations prevented the kind of entry the Government's theories predicted. The Supreme Court affirmed, but this time took the opportunity to develop a general methodology for analyzing actual potential competition mergers.57 According to the Court, "two preconditions must exist" before an actual potential competition theory "establishes a violation of $\S 7$, , 58 (1) that the potential competitor could enter the market at issue absent the merger, and (2) such entry would produce a likelihood of deconcentration or other significant procompetitive effects.59 Moreover, with respect to the first prong, the Court implied that "unequivocal proof" of actual future de novo entry is required. The standard of proof for the second prong is also exacting. The potential entry must accomplish more than simply increase competitive rivalry. It must deconcentrate the market or accomplish another "significant" but unspecified procompetitive transformation. Moreover, the Court expressed doubt that an actual potential competition case would be viable, even when these exacting standards are met. Because the Government did not meet its burden regarding Marine Bancorporation the Court would "express no view on the appropriate resolution of the question reserved in Falstaff."60

Lower Court interpretations of the binding precedent set forth in Marine Bancorporation demonstrate both the unworkable nature of the proof requirements, and the difficulties attendant to requiring the judiciary to grapple with complicated conduct and performance predictions. For example, a few years after the Marine Bancorporation decision, the Fourth Circuit considered a

57 For the perceived potential competition theory, the required showing is that the acquired firm is a perceived entrant and that this perception "tempers" noncompetitive behavior in the market. 418 U.S. at 640.

58 However, in another part of the opinion, the Court states that "Indeed, since the preconditions for that theory are not present, we do not reach it, and therefore we express no view on the appropriate resolution of the question reserved in Falstaff." 418 U.S. at 639. In Fraser v. Major League Soccer, 284 F.3d 47 (1 1 st Cir. 2002), the Court refused to find that $\S 7$ of the Clayton Act can be violated by the elimination of actual potential competition. The Court stated that "It is uncertain how the Supreme Court will ultimately resolve the issue." 284 F. $3 \mathrm{~d}$ at 70.

59418 U.S. at 633.

60418 U.S. at 639. 
potential competition claim by the FTC in 1977 in FTC v. Atlantic Richfield Co.61 The case involved the acquisition of Anaconda, a copper and aluminum mining and processing company by ARCO a large oil and petroleum company. The FTC claimed that ARCO was a likely entrant into the copper market. The Court interpreted Supreme Court precedent to require "clear proof" of entry (citing to the Marine Bancorporation standard of "unequivocal proof"). 62 The Court then relied on the testimony of ARCO's management; precisely the type of evidence eschewed by Fallstaff, and found that "Arco would never seriously consider original entry or entry by toehold acquisition."'63 Lack of proof of entry also doomed the government's cases in BOC International v. British Oxygen, 557 F. 2d 24 (2nd Cir. 1977); Tenneco v. FTC, 689 F.2d 346 (2nd Cir. 1982); United States v. Siemens Corp., 621 F.2d 499 (2nd Cir. 1980); Fraser v. Major League Soccer, 284 F.3d 47 (1st Cir. 2002).

The Fifth Circuit, in Mercantile Texas Corp v. Board of Governors of the Federal Reserve System,64 set forth a detailed analysis of its understanding of the proof requirements of an actual potential competition violation of the Clayton Act.65 According to that Court, the required elements are (1) a concentrated market, (2) no other potential entrants exist other than the target (or acquirer), (3) probability of procompetitive entry and (4) procompetitive effects of independent entry.66 The Court stated that when there are several potential entrants, the elimination of any one

61549 F.2d 289 (4th Cir. 1977).

62 See United States v. Siemens Corp, 621 F.2d 499, 506-507 (2nd Cir. 1980) ("Assuming that the theory of elimination of actual potential competition may be the basis of preliminary injunctive relief, about which some respected authorities have voiced understandable doubt, there must, for purposes of determining whether such relief is appropriate, be at least a 'reasonable probability' that the acquiring firm would enter the market, and preferably clear proof that entry would occur..."); but see, Yamaha Motor Co. v. FTC, 657 F.2d 971, 977 (8th Cir. 1981) (requiring that the potential entrant have "available feasible means" for entering the relevant market, not clear proof of eventual entry). 63549 F.2d at 297. 64638 F.2d 1255 (5th Cir. 1981). 65638 F.2d at 1266-1268.

66 The Fifth Circuit declined to follow the Fourth Circuit and require "entry of the outside firm must appear to be certain" instead it endorsed a standard of proof of "reasonable probability" of entry. 638 F.2d at 1268. 
entrant would not be significant. It then added, following Richard Posner, that "economic theory suggests that, where oligopoly profits are available, a multitude of firms will eagerly seek to enter the market." 67 Thus, the proponent of an actual potential competition case must show in the Fifth Circuit, contrary to the general case, that the specific facts at issue suggest that only the target (or acquiring) firm is a likely entrant. Thus, the Court found that the plaintiff failed to demonstrate that the actual potential competition was "significant" because of the presence of other unanalyzed potential entrants and that there was insufficient evidence that entry would have had a "significant" procompetitive effect.68

The Department of Justice addressed the potential competition issue again in the 1982 Merger Guidelines drafted by the Chicago School influenced appointees of Ronald Reagan. They were revised in 1984, and this was the last time potential competition mergers are addressed by the Merger Guidelines. The 1984 Merger Guidelines built upon but also significantly revised the Justice Department's position developed in the 1968 Merger Guidelines. The 1984 Merger Guidelines treat perceived and actual potential competition together, thus implicitly rejecting the artificial division made by the Supreme Court. The factors that the Department of Justice considers are: (1) the acquired firm's market must be concentrated, above 1800 HHI.69 (2) The acquiring firm must have specific entry advantages; otherwise, the elimination of the target still leaves many potential entrants. The number of firms likely to enter should be less than three. If there are more

67638 F.2d at 1267. Posner writes that "The doctrine of potential competition was introduced into antitrust law by the Supreme Court, and the Court can abandon it-and should do so." Posner's critique of the potential competition doctrine is that it is impossible to determine the universe of potential entrants at any time, let alone the likelihood that each would enter. Richard Posner, Antitrust Law: An Economic Perspective, Univ. of Chi. (1976). 68 The Government prevailed on its potential competition claims in Polypore International v. Federal Trade Commission, 868 F.3d 1208 (11th Cir. 2012) and Yamaha v. Federal Trade Commission, 657 F.2d 971 (8th Cir. 1981).

69 The Herfindahl-Hirschman Index (HHI) is a measure of market concentration equal to the sum of squared market shares and bounded between 0 and 10,000. Markets demonstrating an HHI of greater than 1800 are considered highly concentrated. 
than three likely entrants then there must be direct evidence of likely entry. (3) The target must have a larger market share of 20 percent or more to make a challenge likely. (4) The 1984 Merger Guidelines also require an analysis of the efficiencies of the proposed merger.

The 1984 Merger Guidelines are both a step forward and a step back from the 1968 Merger Guidelines. Unlike the 1968 Merger Guidelines, the 1984 version assumes that the acquiring firm is the potential entrant. The Department of Justice should have made clear that the potential competition doctrine can be applied in either direction; a merger can prevent entry by the acquiring firm or the acquired firm. The 1984 Merger Guidelines further provide that where entry is easy no merger challenge will be undertaken. This is a step backward from the 1968 Merger Guidelines. The 1984 Merger Guidelines never define ease of entry. At most, the 1984 Merger Guidelines declare that ease of entry is the likelihood and probable magnitude of entry in response to a small but significant and nontransitory increase in price.70 While the newer version of the Merger Guidelines adds structure to the more opaque 1968 Merger Guidelines, it relies on another undefined concept, "entry advantage." As the antitrust scholar Joseph Brodley points out, the most probable market entrant under the analytical structure of the 1984 Merger Guidelines is the firm that would achieve the greatest anticipated return from entry.71 According to Brodley:

Courts lack the expertise to resolve complex and speculative factual issues as to future costs and economic conditions. The cases are bound to be burdensome and expensive, especially when competing experts escalate the subtlety of the analysis. 72

701984 Merger Guidelines $§ 3.3$.

71 Joseph Bodley, Potential Competition under the Merger Guidelines, 71 Calif. L. Rev. 376, 390 (1983) (discussing the 1982 Merger Guidelines). The 1982 and 1984 Merger Guidelines treat potential competition mergers in an equivalent way. The 1984 Merger Guidelines added a sentence stating that efficiencies will be considered. $72 I d$. at 391. 
Brodley is correct. Analysis of entry under the Merger Guidelines requires a fairly sophisticated predictive financial analysis. To require a similar analysis for firms that are not parties to the analysis appears intractable.

Thus, the plaintiff asserting a violation of $\S 7$ of the Clayton Act against a dominant firm in a digital market seeking to acquire a start-up based on actual potential competition has a difficult uphill climb. First, many Circuits do not recognize a reduction of actual potential competition as a viable theory under $\S 7$ of the Clayton Act. Second, most courts, but not all, have considered the situation where the acquirer is the potential entrant rather than the incumbent, dominant firm. Third, the courts have demanded a high standard of proof for demonstrating that the start-up would likely enter the market dominated by the acquirer. Fourth, even where entry is likely, the Courts require that the target be uniquely situated to enter and not be one of many potential entrants. Fifth, the Courts require proof that the start-up's entry will significantly reduce the dominance of the dominant firm in its relevant market. These onerous requirements would deter even the most committed antitrust enforcer or plaintiff.

\section{APPLICATION OF THE POTENTIAL COMPETITION DOCTRINE TO THE INSTAGRAM AND WHATSAPP MERGERS.}

In this section of this paper, we describe the difficulty of applying the potential competition doctrine to two widely-criticized Facebook acquisitions, the acquisition of Instagram and the acquisition of WhatsApp. Our intent is not to demonstrate that these acquisitions were anticompetitive, but to show that the potential competition doctrine as presently formulated does not allow for a serious inquiry into the numerous tech mergers described above.73

73 Many commentators have suggested that the Instagram acquisition was anticompetitive. E.g., Jonathan Baker, The Antitrust Paradigm: Restoring a Competitive Economy 161 (2019) (“Consider Facebook's acquisition of Instagram in 2012. This merger could have harmed future competition by reducing incentives to innovate"); Carl Shapiro, Antitrust in a Time of Populism, 61 Int. J. of Ind. Org. 714, 740 (2018) (“One common fact pattern that can involve a loss of future competition occurs when a large incumbent firm acquires a highly capable firm operating in an adjacent 


\section{A. The Instagram Acquisition}

When Facebook announced its \$1 billion acquisition of Instagram on April 9, 2012 it was something of an anomaly.74 Although Facebook had made 31 acquisitions up to this point, none approached the price tag paid for Instagram.75 However, Instagram was different, and the opportunity arose at a critical crossroad for Facebook. On the eve of its May 2012 IPO, Facebook was under great pressure by investors to increase its revenue base. At the same time, the rise of mobile technology and its rapid adoption by consumers created hurdles for Facebook to satisfy these demands. Two problems confronted the company as an increasing share of users accessed the internet from mobile devices. First, Facebook struggled to reorient its network from a desktopbased platform, and second, it had yet to monetize its mobile user base by incorporating advertising on the limited display area available on mobile screens.76 As other companies developed mobilefirst applications that optimized web access using smartphones, Facebook elected to invest in an HTML5-based multi-platform strategy. On mobile devices their HTML5 approach was slower and less stable than native iOS and Android applications.77 At the same time mobile-native applications with social features such as Instagram and Foursquare were attracting growing user numbers and

space. This happens frequently in the technology sector. Prominent examples include Google's acquisition of YouTube in 2006 and DoubleClick in 2007, Facebook's acquisition of Instagram in 2012...”).

74 Evelyn Rusli, Facebook Buys Instagram for \$1 Billion, New York Times, April 9, 2012.

75 See Appendix.

76 In Facebook's 2012 SEC Form S-1 Registration Statement, the company records 845 million monthly active users, and 425 million monthly active users accessing the network through mobile products in December 2011. Among the company's risk factors are two mobile-related risks: (1) "Growth in use of Facebook through our mobile products, where we do not currently display ads, as a substitute for use on personal computers may negatively affect our revenue and financial results;" and (2) "Facebook user growth and engagement on mobile devices depend upon effective operation with mobile operating systems, networks, and standards that we do not control." SEC Filing S-1, available at Facebook Investor Relations https://investor.fb.com/financials/?section=secfilings and http://d1lge852tjjqow.cloudfront.net/CIK-0001326801/f3fcb2a3-f76a-4aaa-9c7c-9fa100fdc962.pdf. 77 MG Siegler, Facebook For iPhone Updated: No iOS 4 Support, No iPad Support, Broken UI, TechCrunch, June 19, 2010, https://techcrunch.com/2010/06/19/facebook-iphone-app/. Drew Olanoff, Mark Zuckerberg: Our Biggest Mistake Was Betting Too Much on HTML5, TechCrunch, September 11, 2012, https://techcrunch.com/2012/09/11/mark-zuckerberg-our-biggest-mistake-with-mobile-was-betting-too-much-onhtm15/. Om Malik, Here is why Facebook bought Instagram, GigaOm, Apr. 9, 2012 - 11:28 AM CDT, https://gigaom.com/2012/04/09/here-is-why-did-facebook-bought-instagram/. 
threatened to draw user engagement away from Facebook precisely when its revenue base was under scrutiny.

Photo sharing had been a key facet of Facebook's user engagement since its introduction on the network. By 2009 Facebook Photos was the largest photo sharing service in the world.78 In ensuing years as dramatic improvements in smartphone camera features made photo sharing an increasingly mobile-based activity Facebook struggled to adapt to the shift to mobile technology. At this pivotal juncture, Stanford engineering graduates Kevin Systrom and Mike Krieger launched the native iOS photo sharing social network Instagram. On Instagram users could upload, edit, and share pictures from their iPhones and follow, comment, and like the images posted by others. The app also enabled users to post their Instagram images interoperably across social networks, including Facebook and Twitter. But the founders did not aim to be a mere content creator for other social networks. Rather, Systrom and Krieger envisioned their app as a rival to the incumbent social networking giants based on a community united under the premise that "the next network is people interested in sharing life visually."79 The company was poised to compete in the social networking market. As Tim Wu describes:

What made Instagram especially dangerous to Facebook was that it was strong where Facebook was weak. Instagram was native to mobile; Facebook was struggling on that platform. And photo sharing was incredibly fast and easy on Instagram. As business writer Nicholas Carlson observed, Instagram 'allows people to do what they like to do on Facebook easier and faster.' Perhaps even more alarming, Instagram appealed to a younger demographic and had a cachet that Facebook was starting to lose." 80

78 Erick Schonfeld, Facebook Photos Pulls Away From the Pack, TechCrunch, February 22, 2009, https://techcrunch.com/2009/02/22/facebook-photos-pulls-away-from-the-pack/.

79 Claire Cain Miller, A Photo-Sharing App With Bigger Aspirations, New York Times: Bits, Oct. 19, 2010, https://bits.blogs.nytimes.com/2010/10/19/a-photo-sharing-app-with-bigger-aspirations/.

80 Tim Wu, It's not too late to create a meaningful check on the power of Mark Zuckerberg's company, The Washington Post, September 28, 2018. 
Within the first week of its October 6, 2010 launch on the Apple App Store, Instagram had garnered 100,000 user downloads.81 Ten weeks later it had accrued over 1 million registered users. 82 The company quickly attracted the attention of venture capital that would allow it to scale. The firm's initial funding round brought former Facebook VP of Product Management Matt Cohler to Instagram's Board of Directors, who advised the company to pursue growth first without monetization in order to achieve the network effects that would drive advertising revenue later. 83 One month before the company revealed its acquisition, just two and half years after its introduction on the App Store, Instagram founder Kevin Systrom announced that Instagram had reached 27 million registered users and "Facebook-level engagement." 84 In the following weeks Instagram branched out from iOS to launch on Android and brought in 1 million new users in the first 24 hours. 85 When Facebook and Instagram announced the acquisition six days after the Android launch, Instagram had over 30 million users and just 13 employees.86

According to Silicon Valley folklore, Zuckerberg invited Systrom to his home on a Saturday. By Monday the billion-dollar deal was done.87 Observers at the time registered their suspicions that the acquisition was an act of "squashing a potential rival" and pointed to the impending monetization of Instagram as a source of competition that could have driven down prices in online advertising markets. 88 The merger triggered a Hart-Scott-Rodino filing, but

81 MG Seigler, Instagram Captures 100,000 Mobile Photo Addicts in Less Than a Week, TechCrunch, Oct. 13, 2010, https://techcrunch.com/2010/10/13/instagram-users/.

82 MG Siegler, Instagram Captures A Million Users. Up Next: API, Android, And Funding, TechCrunch, December 21, 2012, https://techcrunch.com/2010/12/21/instagram-one-million/.

83 Kim-Mai Cutler. From 0 to $\$ 1$ billion in two years: Instagram's rose-tinted ride to glory, TechCrunch, Apr 9

2012, https://techcrunch.com/2012/04/09/instagram-story-facebook-acquisition/.

84 Id.

85 Id.

86 Thomas Houston, Facebook to buy Instagram for \$1 Billion, The Verge, April 9, 2012, https://www.theverge.com/2012/4/9/2936375/facebook-buys-instagram.

87 Steven Bertoni, The Stanford Billionaire Machine Strikes Again, Forbes, August 1, 2012.

88 In The New York Times Somini Sengupta points directly at issues of potential competition, stating, "Instagram had no advertisements, but it could have one day started to attract advertisements. That would have meant real competition for Facebook, especially on mobile devices, where the social network has been unable to, by its own 
ultimately the antitrust agencies took no action. The FTC investigation was nonpublic and enforcers did not disclose the basis for their decision at the time. One likely obstacle was the user price of zero set by Facebook and Instagram for their social networking services, which complicates estimates of markups above the competitive price or estimates of entry in response to a small price increase. In the social networking market, companies compete for user attention. The consumer-facing market generally has a price of zero, with services monetized in the advertising market by selling access to the user attention captured on the social network. Instagram operated in the social networking market and it was encouraging users to defect from Facebook to Instagram, but the competitive dimensions of this market are challenging to measure and interpret since users may participate on both networks and neither network charged for the services involved. Several economists have offered solutions to this problem including measures of user engagement such as the number of users or the amount of time spent on a website. 89 By any reasonable measure, Instagram was already a competitor.90

In contrast, advertising markets are not free. Digital advertising market analysts widely acknowledge the dominance of a duopoly in digital advertising composed of Google and Facebook

admission, generate "meaningful revenue." A rival that happens to be hugely popular on mobiles could have potentially driven down advertising prices." Somini Sengupta, Why Would the Feds Investigate the FacebookInstagram Deal? The New York Times May 10, 2012, https://bits.blogs.nytimes.com/2012/05/10/why-would-thefeds-be-probing-the-facebook-instagram-deal. According to TechCrunch, "Last year, documents for a standalone Facebook mobile photo sharing app were attained by TechCrunch. Now it seems Facebook would rather buy Instagram which comes with a built-in community of photographers and photo lovers, while simultaneously squashing a threat to its dominance in photo sharing." Facebook Buys Instagram For \$1 Billion, Turns Budding Rival into its Standalone Photo App, TechCrunch April 9, 2012, https://techcrunch.com/2012/04/09/facebook-toacquire-instagram-for-1-billion/.

${ }_{89}$ David S. Evans, Attention Rivalry Among Online Platforms, 9 J. COMPETITION L. \& ECON. 313 (2013), John Newman, Antitrust in Zero-Price Markets: Foundations, 164 Univ. of Penn. L. Rev. 149 (2015); Tim Wu, Blind Spot: The Attention Economy and the Law, Antitrust Law Journal (2017).

90 According to Facebook's 2012 Annual Report, the company believed that Instagram was drawing users away from engagement with Facebook, stating, "We believe that some of our users have reduced their engagement with Facebook in favor of increased engagement with other products and services such as Instagram." SEC Form 10K for the fiscal year ended December 31, 2012, available at Facebook Investor Relations https://investor.fb.com/financials/?section=annualreports and https://s21.q4cdn.com/399680738/files/doc_financials/annual_reports/FB_2012_10K.pdf. 
which jointly claim approximately 60 percent of total revenue in the market.91 For Facebook that dominance amounted to $\$ 16.6$ billion in advertising income during the second quarter of 2019 , and more than 98 percent of its total revenue.92 Facebook's advertising market power is even more significant when compared to similar advertising platforms. For example, during the 2007 investigation of the Google/DoubleClick merger the FTC determined that search advertising (advertising delivered in response to a consumer search query) should be separated from display advertising (including image, video, rich media, etc., purchased on a webpage). According to the FTC, "the evidence shows that the sale of search advertising does not operate as a significant constraint on the prices or quality of other online advertising sold directly or indirectly by publishers or vice versa."93

Today Facebook leads the market in digital display advertising with a market share of over 40 percent.94 Arguably, an even smaller relevant market might exist for advertising on social networks.95 In 2011 and 2012, as Facebook struggled to monetize its mobile user base, Google and Facebook battled for the top spot, each controlling about 14 percent of the digital display advertising market in 2011 and 15 percent in 2012.96 At the time of the merger, the majority of

91 EMarketer, U.S. Digital Ad Spending Will Surpass Traditional in 2019, February 2019, https://www.emarketer.com/content/us-digital-ad-spending-will-surpass-traditional-in-2019. AppNexus The Digital Advertising Stats You Need for 2018 https://www.appnexus.com/sites/default/files/whitepapers/guide2018stats_2.pdf. 92 Facebook Investor Relations, Facebook Q2 2019 Results Presentation Slides, https://s21.q4cdn.com/399680738/files/doc_financials/2019/Q2/Q2-2019-Earnings-Presentation-07.24.2019.pdf. 93 Statement of the Federal Trade Commission Concerning Google/DoubleClick, FTC File No. 071-0170, https://www.ftc.gov/system/files/documents/public_statements/418081/071220googledc-commstmt.pdf. 94 Ginny Marvin, Report: Facebook's display ad domination to grow as US digital ad spend hits $\$ 83 B$ in 2017 , MarketingLand March 14, 2017, https://marketingland.com/emarketer-facebook-dominate-15-9-pct-digital-adspend-growth-2017-209045.

95 Jonathan Baker, The Antitrust Paradigm: Restoring a Competitive Economy 162-163 (2019) ("Instagram was one of a few significant potential rivals to Facebook with the capability of someday offering attractive advertising services on a social network. If social networks were, or were likely to become, particularly good vehicles for some types of advertisers, and more attractive to those advertisers than advertising in response to user searches, then Facebook and Instagram would have been close rivals in an innovation market and a future product market for advertising on social media platforms.") 96eMarketer, Google, Facebook Continue to Lead in Digital Display Earnings, March 29, 2013, https://www.emarketer.com/Article/Google-Facebook-Continue-Lead-Digital-Display-Earnings/1009769. 
Facebook's revenue came from display advertising. 97 Instagram did not sell advertising at the time of the acquisition, but it had been working directly with brands to support image-oriented ways of connecting companies with users. 98 As the Instagram network grew, more businesses saw it as an important medium to reach consumers. 99 When Instagram was ready for monetization, it would be unlikely to charge users for social networking services in a market where the going price was zero. Once Instagram introduced advertising it would likely compete with Facebook in the digital display advertising market as well as social networking. Instagram was an actual potential entrant in both of these markets. Thus the Instagram merger presented a classic case of a potential competition merger under $\S 7$ of the Clayton Act.

Although the FTC did not outline the considerations that guided its investigation, in August 2012 the UK's Office of Fair Trading (OFT) published an outline of its decision to refrain from referring the Instagram acquisition to the Competition Commission. The OFT determined that Instagram was an actual current competitor in social networking services, and that Facebook's large share of the market achieved the threshold for investigation.100 The OFT interpreted

${ }_{97}$ The UK's Office of Fair Trading notes that the majority of Facebook's advertising is display advertising, and the company's annual report shows that 83.8 percent of total revenues come from advertising. Office of Fair Trading, Full Text of the Decision Regarding the Anticipated Acquisition by Facebook Inc of Instagram Inc, August 22, 2012 https://webarchive.nationalarchives.gov.uk/20140402232639/http://www.oft.gov.uk/shared_oft/mergers_ea02/2012/ facebook.pdf. SEC Form 10K for the fiscal year ended December 31, 2012, available at Facebook Investor Relations https://investor.fb.com/financials/?section=annualreports and https://s21.q4cdn.com/399680738/files/doc_financials/annual_reports/FB_2012_10K.pdf. 98 MG Siegler, Beyond the Filters: Brands Begin to Pour into Instagram, TechCrunch, January 13, 2011, https://techcrunch.com/2011/01/13/instagram-brands/. MG Siegler, Instagram Taps Hashtags to Bundle Pictures; Brands Quickly Jump On Board, TechCrunch January 27, 2011, https://techcrunch.com/2011/01/27/instagramhashtags/.

99 MG Siegler, Beyond the Filters: Brands Begin to Pour into Instagram, TechCrunch, January 13, 2011, https://techcrunch.com/2011/01/13/instagram-brands/.

100 According to the release, "The parties overlap in the supply of virtual social networking services. Facebook's share of supply in the UK of virtual social networking services is over 25 per cent and, given that Instagram is active in the supply of virtual social networking services, the Transaction would result in an increment. Consequently, the share of supply test in section 23 of the Act is met." Office of Fair Trading, Full Text of the Decision Regarding the Anticipated Acquisition by Facebook Inc of Instagram Inc, No. ME/5525/12 August 22, 2012, II 5,

https://webarchive.nationalarchives.gov.uk/20140402232639/http://www.oft.gov.uk/shared_oft/mergers_ea02/2012/ facebook.pdf. 
Instagram's rapid growth as an indication of low barriers to entry in social networking and photo sharing, concluding that Instagram did not evince a uniquely competitive product such that its acquisition would foreclose competition in either market.101 They did consider Instagram as a potential competitor in digital advertising markets but determined that Facebook's competition from Google, Yahoo, and Microsoft dwarfed the potential competitive impact of entry by Instagram and determined that there was "no realistic prospect that the merger may result in a substantial lessening of competition in the supply of display advertising."102

Today, Facebook claims a dominant position in the social networking and online social photo services markets, and market power through the Facebook-Google duopoly over digital advertising. If the antitrust agencies faltered, it was likely because the potential competition doctrine created difficult obstacles for a merger challenge. Consider the following facts of the Instagram merger in light of the required proof under the 1984 Merger Guidelines to justify a Department of Justice challenge.

\section{Market Concentration}

The 1984 Merger Guidelines state that a challenge is unlikely if concentration in the acquired firm's market is below $1800 \mathrm{HHI} .103$ In the case of the Instagram merger the relevant market to measure concentration would be the acquiring firm's market. Facebook operates in markets for social networking and digital advertising. By 2011, Facebook dominated the social

101 'In terms of whether other apps or social networks could replicate Instagram's success, it is relevant that Instagram grew rapidly from having 1.4 million users in January 2011 to around 24 million users in February 2012. Whilst this indicates the strength of Instagram's product, it also indicates that barriers to expansion are relatively low and that the attractiveness of apps can be 'faddish'." Office of Fair Trading, Full Text of the Decision Regarding the Anticipated Acquisition by Facebook Inc of Instagram Inc, No. ME/5525/12 August 22, 2012, II 36, https://webarchive.nationalarchives.gov.uk/20140402232639/http://www.oft.gov.uk/shared_oft/mergers_ea02/2012/ facebook.pdf. 102 Office of Fair Trading, Full Text of the Decision Regarding the Anticipated Acquisition by Facebook Inc of Instagram Inc, No. ME/5525/12 August 22, 2012, II 29,

https://webarchive.nationalarchives.gov.uk/20140402232639/http://www.oft.gov.uk/shared_oft/mergers_ea02/2012/ facebook.pdf.

103 See Supra 70 for the definition of HHI. 
networking industry by a wide margin in terms of user numbers and engagement but $\mathrm{HHI}$ calculations lack defined measures for markets where the user price is zero.104 A workable measure of concentration is critical for markets like social networking in which the good or service is free. As zero-price markets proliferate antitrust institutions must adopt new instruments for analysis or risk the amplification of consumer harms.105 Scholarship on the application of antitrust in these markets suggests that enforcement focus on attention and informational costs, or metrics such as "time on site" that could be used to indicate the extent of competition for user engagement. 106 Such a measure could have demonstrated important implications of a Facebook-Instagram merger for competition in the market.

In the digital advertising market, the Facebook-Google duopoly already controlled 45.5 percent of revenue in 2011, although the majority of that share was attributable to Google.107 Narrowing the scope to the display advertising the market, the top six firms in 2011 collected approximately 49 percent of the digital display advertising revenue and the HHI among those six firms amounted to just 546.108 In the years following the 2012 acquisition of Instagram the

104 Hampton, Keith N., Goulet, Lauren Sessions, Rainie, Lee \& Purcell, Kristen, Social Networking Sites and Our Lives, Pew Research Center, June 2011 (2011) https://www.pewinternet.org/wpcontent/uploads/sites/9/media/Files/Reports/2011/PIP-Social-networking-sites-and-our-lives.pdf. 105 John Newman, Antitrust in Zero-Price Markets: Foundations, 164 Univ. of Penn. L. Rev. 149 (2015). 106 Newman argues that free products are not, in fact, free and thus involve measurable changes in the cost to consumers, stating: "Consumers of zero-price products pay for those products, at least when the zero-price products are offered as part of a sustainable business model. In the absence of a tying arrangement involving some positiveprice product, consumers generally pay with their attention, information, or both." John Newman, Antitrust in ZeroPrice Markets: Foundations, 164 Univ. of Penn. L. Rev. 149 (2015). Tim Wu argues for time on site as a readily available proxy for market share in attention, stating, "One relatively simple way of measuring market power in attentional markets is to focus on the industry's own metric: time, or in the jargon, "time on site." Time serves as a proxy for attention, given that one cannot usually determine whether consumers are actually attending to their screens when advertisements are displayed or how focused that attention is at any given moment. This approach recognizes that some firms are at the junction of two markets - attention and cash markets - and appreciates that market power in attention markets can convey considerable power." Tim Wu, Blind Spot: The Attention Economy and the Law, Antitrust Law Journal (2017).

107eMarketer, Beyond the Duopoly: Exploring Digital Advertising Outside Google and Facebook December 7, 2017, https://www.emarketer.com/Report/Beyond-Duopoly-Exploring-Digital-Advertising-Outside-GoogleFacebook/2002174. 108 eMarketer, Google, Facebook Continue to Lead in Digital Display Earnings, March 29, 2013, https://www.emarketer.com/Article/Google-Facebook-Continue-Lead-Digital-Display-Earnings/1009769. 
Facebook-Google duopoly consolidated their market power in both the digital advertising and the display advertising markets. By 2018 both markets displayed HHIs of over 1800 and Facebook's share of display advertising revenue in the US market rose to more than 40 percent—even higher if a more narrow market were defined. 109 Thus, while it is likely that a measure of concentration for the social networking market would have satisfied the first prong of the merger guidelines analysis, the concentration levels measured for the display advertising market concentration levels would not have been sufficient.

\section{Conditions of Entry Generally}

The Department of Justice will not challenge a potential competition merger if entry into the market is easy. This protocol requires the Department of Justice to demonstrate some difficulty of entry or barriers to entry in the concentrated market. Through 2011, the markets for social networking and digital advertising had been dynamic as firms in these markets competed for dominance. The economies of scale and network effects that typify platform markets represent traditional barriers to entry that would reinforce the incumbency of dominant firms, but Instagram was showing the potential for a nascent competitor to siphon off users and gain market share. Entry into social networking or digital advertising markets was achievable for small and start-up firms that operated in any of several adjacent markets if they exhibited the rapid growth in user engagement that would lead to increasing value on both sides of the market and if they had access to the funding that would allow the company to scale up.

109 EMarketer, U.S. Digital Ad Spending Will Surpass Traditional in 2019, February 2019, https://www.emarketer.com/content/us-digital-ad-spending-will-surpass-traditional-in-2019. Ginny Marvin, Report: Facebook's display ad domination to grow as US digital ad spend hits \$83B in 2017, MarketingLand, March 14, 2017, https://marketingland.com/emarketer-facebook-dominate-15-9-pct-digital-ad-spend-growth-2017-209045. 
There is one significant barrier to entry in online platform markets that is unlike the traditional barriers considered in other markets: access to data.110 A dominant firm with access to broad user data has a significant advantage over new entrants. The data advantage allows a dominant firm to reinforce its market power in three ways. The firm can use data to review and improve user services in the core market and expand user engagement, generating more data. The firm can leverage its data advantage to reach new users through entry into adjacent markets and likewise expand its data access. Finally, the scope and magnitude of consumer data available to a dominant firm allows it to sell high-value targeted advertising with revenues that may be invested in increasing user engagement and amassing more consumer data. These three advantages create a positive feedback loop for the dominant firm.111 The drive to exploit user attention and access to data may translate to gains for consumers who enjoy higher quality services and seemingly individuated advertising. For start-ups with comparatively little data access the competitive advantage of large firms' data scale and efficiencies poses a significant barrier to entry. As a result of these advantages, the dominant consumer-facing platforms also dominate advertising marketsa tendency exemplified in the Facebook-Google duopoly.

Despite these structural barriers, demonstrating the difficulty of entry into the social networking or digital advertising markets presents a challenge. For one thing, the data barrier is specific to online platform markets. For another, competition for user attention forces the dominant firm to compete with platforms and applications operating across a variety of markets. There is no

110 Jason Furman et al., Unlocking Digital Competition: Report of the Digital Competition Expert Panel HM Treasury Digital Competition Expert Panel, March 2019, page 33, https://assets.publishing.service.gov.uk/government/uploads/system/uploads/attachment_data/file/785547/unlocking _digital_competition_furman_review_web.pdf.

111 Jason Furman et al., Unlocking Digital Competition: Report of the Digital Competition Expert Panel HM Treasury Digital Competition Expert Panel, March 2019, page 34, https://assets.publishing.service.gov.uk/government/uploads/system/uploads/attachment_data/file/785547/unlocking _digital_competition_furman_review_web.pdf. 
direct substitute for Facebook in the social networking market, but smaller firms offering complementary or adjacent features have the ability to capture user attention that draws engagement and profits away from the network, even if the smaller firm is not competing in social networking.112 This ability to capture user attention also makes these smaller, adjacent firms potential competitors in digital advertising. Extending consideration to potential competitors in adjacent markets where entry is relatively easy could undermine the government's ability to isolate any impact from the elimination of a single rival.

\section{The Target Firm's Entry Advantage}

If entry is not easy generally, then the Department of Justice has to show that Instagram had an entry advantage not possessed by three or more firms. The potential for firms to enter social networking or digital advertising markets from a variety of adjacent or complementary markets makes it impossible to identify limits to potential entrants. Isolating the photo sharing market in the case of Instagram provides a good example of this difficulty.

Despite Facebook's dominance in photo sharing, several desktop-based and mobile applications existed at the time. Most of these platforms lacked the social features that distinguished the social networking elements available through Facebook and Instagram. Facebook even purchased several other photo-related services leading up to the Instagram acquisition, including the photo sharing and tagging website Divvyshot in April 2010, the file sharing, messaging, and commenting service Drop.io in October 2010, and video and image recording and editing app developer Digital Staircase in November 2011.113 In May 2012, after

112 During a 2018 Congressional hearing Facebook CEO Mark Zuckerberg responded to the question "Who's your biggest competitor?" by insisting that the company competes in three main categories, rather than facing a direct competitor in one primary market. Zuckerberg also mentioned that a typical American uses eight different communications software applications, but did not mention that Facebook owns several of them. Transcript of Mark Zuckerberg's Senate Hearing. U.S. Senate 115th Congress, 2nd Session Sess. (2018)

https://www.washingtonpost.com/news/the-switch/wp/2018/04/10/transcript-of-mark-zuckerbergs-senate-hearing/. 113 See Appendix. 
announcing the Instagram acquisition but before it was finalized, Facebook purchased Lightbox.com, a mobile social photo sharing application designed for Android in the period before Instagram introduced its Android app. While Lightbox had amassed 1.5 million downloads in its first seven months of operation, Instagram's Android launch in April reached 1 million within a week.114 Facebook purchased and shuttered the Lightbox application, absorbing its employees and pulling the app from the market immediately.115 Facebook launched its own camera app, Facebook Camera, on May 24, 2012, weeks after announcing its intention to acquire Instagram.116

The UK's OFT decision lists six competing apps in the photo sharing market, including Camera Awesome, Camera +, Flickr, Hipstamatic, Path, and Pixable.117 Of these services, only Camera+, Hipstamatic, and Camera Awesome included camera applications. Flickr is a photo storage and management tool and Pixable was an aggregator that scraped images from social networks including Facebook, Twitter, and Instagram.118 Path was a social network conceived as a competitor to Facebook that offered a more private experience, limiting social connections to invite more personal interactions.119 Hipstamatic and Camera+ provided photo taking and editing tools but lacked the social features that distinguished Instagram.120 In addition, Hipstamatic and

114 Naina Khedekar, Interview with Stephen Robert Morse from Lightbox, Firstpost Jan. 18, 2012, https://www.firstpost.com/tech/news-analysis/interview-with-stephen-robert-morse-from-lightbox-3593563.html. 115 Josh Constine, Facebook Hires Team From Android Photosharing App Dev Lightbox To Quiet Mobile Fears, TechCrunch, May 15, 2012, available at https://techcrunch.com/2012/05/15/facebook-lightbox/. 116 Dirk Stoop, Introducing Facebook Camera, Facebook Newsroom May 24, 2012, https://newsroom.fb.com/news/2012/05/introducing-facebook-camera/. 117 Office of Fair Trading, Full Text of the Decision Regarding the Anticipated Acquisition by Facebook Inc of Instagram Inc, No. ME/5525/12 August 22, 2012,

https://webarchive.nationalarchives.gov.uk/20140402232639/http://www.oft.gov.uk/shared_oft/mergers_ea02/2012/ facebook.pdf.

${ }_{11}$ Chris Anderson, Pixable Closing Up Shop After One Crazy, Awesome Ride, Medium, November 30, 2015, https://medium.com/@chris_anderson/pixable-closing-up-shop-after-one-crazy-awesome-ride-59192743528b. 119 Elise Moreau, A Look Back on the Social Networking App Called Path, Lifewire, June 1, 2019, https://www.lifewire.com/what-is-path-3486483. Jon Russell, Mobile social network Path, once a challenger to Facebook, is closing down, TechCrunch September 17, 2018, https://techcrunch.com/2018/09/17/rip-path/. 120 According to Hipstamatic cofounder Lucas Buick, "We've never been a social networking company, but we clearly benefit from social networks." Quoted in Austin Carr, Exclusive: Hipstamatic, Instagram To Unveil PhotoSharing Partnership, Fast Company, March 21, 2012, https://www.fastcompany.com/1824797/exclusivehipstamatic-instagram-unveil-photo-sharing-partnership. 
Camera Awesome had entered into a partnership with Instagram that streamlined posting photos taken with those apps to Instagram's social network.121 The OFT's list of competitors illustrates the difficulty of identifying potential entrants in the social networking or digital advertising markets. In online platform markets new entrants often offer just a subset of the services offered by the dominant provider.122 Firms like Instagram that gain the popularity and funding to scale become rivals for user attention and potentially rivals for the market over time. Facebook would likely argue that Instagram is just one of many potential entrants into social networking, and that any of the other photo sharing apps could replace the potential competition lost through the Instagram acquisition. Moreover, when consumers multi-home by using several apps at once entry by multiple firms becomes even more likely.

Facebook named Instagram as an important competitor, but it was not the only competitor. Instagram's entry advantages were the extraordinary user growth rate and venture capital investments that might allow the firm to overcome barriers of scale and data access in the social networking and digital advertising markets. These same advantages gained the attention of Facebook and its buyout proposal.

\section{Deconcentration from Instagram Entry}

The final criteria for a potential competition claim is for the government to show that Instagram's entry into the social networking or advertising markets would deconcentrate the market or have a significant procompetitive effect. Under the Merger Guidelines this effect can be established by showing that Instagram had a market share of five percent or more. In 2012, the

121 Austin Carr, Exclusive: Hipstamatic, Instagram To Unveil Photo-Sharing Partnership, Fast Company, March 21, 2012, https://www.fastcompany.com/1824797/exclusive-hipstamatic-instagram-unveil-photo-sharing-partnership. Kim-Mai Cutler, Bootstrapped Is Better? Smugmug's Camera Awesome Crosses 4 M Downloads, Adds Instagram Support, TechCrunch, March 27, 2012, https://techcrunch.com/2012/03/27/smugmug-camera-awesome/. 122 Jacques Crémer, Yves-Alexandre de Montjoye, \& Heike Schweitzer, Competition Policy for the Digital Era, European Commission, page 57, (2019) http://ec.europa.eu/competition/publications/reports/kd0419345enn.pdf. 
first year Instagram was included in the Pew Social Media Survey, 12 percent of adults - and a significantly higher share of young people - used Instagram despite the fact that it was a mobileonly application.123 There are no attentional measures such as time on site available for the period before acquisition but multi-homing and Instagram's own interoperability would suggest that the company claimed a small share of total social networking users' attention. The market draw for Instagram was its popularity with important demographic groups at a time when Facebook saw reaching young people and their preferred technologies as key to maintaining dominance in the market. As described in Facebook’s 2012 Annual Report,

"Some of our current and potential competitors may have significantly greater resources or better competitive positions in certain product segments, geographic regions or user demographics than we do. These factors may allow our competitors to respond more effectively than us to new or emerging technologies and changes in market conditions. We believe that some of our users, particularly our younger users, are aware of and actively engaging with other products and services similar to, or as a substitute for, Facebook. For example, we believe that some of our users have reduced their engagement with Facebook in favor of increased engagement with other products and services such as Instagram. In the event that our users increasingly engage with other products and services, we may experience a decline in user engagement and our business could be harmed."124

At the time of the Facebook acquisition, Instagram had not entered the digital advertising market and had no advertising revenue. It would be impossible to establish a procompetitive effect of Instagram's entry into the advertising market through the 5 percent threshold because competition from Instagram lay entirely in the future.

123 Lee Rainie, Joanna Brenner, \& Kristin Purcell, Photos and Videos as Social Currency Online, Pew Research Center, September 13, 2012, https://www.pewinternet.org/2012/09/13/photos-and-videos-as-social-currency-online/. 124 SEC Form 10K for the fiscal year ended December 31, 2012, available at Facebook Investor Relations https://investor.fb.com/financials/?section=annualreports and https://s21.q4cdn.com/399680738/files/doc_financials/annual_reports/FB_2012_10K.pdf. 
The potential competition challenge by the Department of Justice would have certainly failed under its own guidelines. But consider the post-acquisition information which retrospectively demonstrates how the Guidelines produce a false negative result. Since the acquisition was finalized in 2012 Instagram has generated a significant share of user engagement and revenue for Facebook. With Facebook's resources and expertise guiding its evolution, Instagram reached 1 billion monthly active users in June 2018 even as Facebook's own user growth dwindled.125 According to the Pew Research Center, Instagram trails Facebook as the second-most popular social network in the US with 37 percent of adults using the platform in 2019.126 It is the most-used social network for American teens. 127 Although Facebook does not disclose Instagram's financial details, market analysts estimate that 15 percent of Facebook's revenues come from advertising on Instagram, a number expected to grow over time.128 In 2019 Instagram launched a checkout feature allowing users to make purchases from within the app and delivering a new source of revenue to its parent company.129 It is impossible to know if Instagram would have developed into such a powerful position without Facebook's guidance, but it is clear that Facebook's ownership of Instagram allows it to reach a larger user base and achieve greater levels

125 Josh Constine, Instagram hits 1 billion monthly users, up from 800M in September, TechCrunch, June 20, 2018, https://techcrunch.com/2018/06/20/instagram-1-billion-users/.

126 Andrew Perrin \& Monica Anderson, Share of U.S. adults using social media, including Facebook, is mostly unchanged since 2018, Pew Research Center, April 10, 2019, https://www.pewresearch.org/facttank/2019/04/10/share-of-u-s-adults-using-social-media-including-facebook-is-mostly-unchanged-since-2018/. 127 Monica Anderson \& JingJing Jiang, Teens, Social Media \& Technology 2018, the Pew Research Center, March 31, 2018, https://www.pewinternet.org/2018/05/31/teens-social-media-technology-2018/. Sean Wolfe, Instagram just surpassed Snapchat as the most used app among American teens, according to a new Wall Street survey, Business Insider, October 22, 2018, https://www.businessinsider.com/instagram-snapchat-popularity-teens-piperjaffray-2018-10.

128 Sara Frier \& Jeran Wittenstein, Facebook's Quarterly Ad Revenue to Get Lift from Instagram, Bloomberg, July 25, 2018, https://www.bloomberg.com/news/articles/2018-07-25/facebook-s-quarterly-ad-revenue-to-get-lift-frominstagram. Kurt Wagner \& Roni Molla, Facebook will soon rely on Instagram for the majority of its ad revenue growth, Vox, October 9, 2018, https://www.vox.com/2018/10/9/17938356/facebook-instagram-future-revenuegrowth-kevin-systrom. Eric Jhonsa, Instagram Has Become Facebook's Main Growth Engine During Its Transition Period, TheStreet, July 12, 2019, https://realmoney.thestreet.com/investing/technology/instagram-has-becomefacebook-s-main-growth-engine-during-its-transition-period-15018209.

129 Josh Constine, Instagram Launches Shopping Checkout, Charging Sellers a Fee, TechCrunch, March 19, 2019, https://techcrunch.com/2019/03/19/instagram-checkout/. 
of user engagement and revenue generation than Facebook alone. The economies of scale and scope that characterize online platform markets are simultaneously a source of efficiency gains from the acquisition of Instagram and a barrier to entry reinforcing Facebook's dominance in the social networking market.

The Instagram case shows that the potential competition doctrine must be reformed. Common sense suggests that concentration must be measured either by an alternative metric in markets where goods are offered to the public without charge, such as user engagement, or possibly by the advertising dollars that flow to social networks. As we discuss in the last section of this paper, concentration should serve as a structural rebuttable presumption when a dominant firm purchases a potential entrant. Before turning to that is sue we briefly discuss Facebook's acquisition of WhatsApp.

\section{B. The WhatsApp Acquisition}

Facebook's \$19 billion acquisition of WhatsApp was another landmark deal. In 2014 mobile messaging applications were the fastest growing app category in the mobile market as social media evolved to accommodate increasing smartphone usage.130 Users relied on these applications for far more than text messaging, with a variety of social activities taking place on the apps including voice calling, image and video sharing, and gaming.131 Five-year-old WhatsApp was already the largest and fastest growing of these applications worldwide. The app offered a reliable and affordable cross-platform technology for text, voice, image, and video sharing in oneto-one or group contexts that worked across national borders and offered end-to-end encryption.

130 Emily Adler, Here's How Many of the Fastest-Growing Messaging Apps Are Already Earning Significant Revenue, Business Insider, November 20, 2014, https://www.businessinsider.com/many-of-the-fastest-growingmessaging-apps-are-already-earning-significant-revenues-2014-11. For mobile uptake see Pew Research Center, Mobile Fact Sheet, June 12, 2019, https://www.pewinternet.org/fact-sheet/mobile/. 131 IPG Media Lab, Messaging Apps: the New Face of Social Media and What it Means for Brands, 2014 https://ipglab.com/wp-content/uploads/2014/04/MessagingApps_Whitepaper_Final.pdf. 
At the time of the acquisition WhatsApp had 450 million monthly active users and was gaining users at a record rate of one million per day.132 Importantly, WhatsApp users were unusually engaged; more than seventy percent of WhatsApp users accessed the app daily and its volume of messaging rivaled the global total of telecom SMS.133 Two characteristics distinguished WhatsApp from its rival messaging services, and from Facebook's corporate model. First, WhatsApp's founders committed the service to almost complete data privacy.134 Second, WhatsApp was advertising-free.135 Instead of the intensive data collection, aggregation, and analysis driving advertising revenue on other apps and networks, the company elected a paid model with most users charged a \$0.99 annual subscription fee after their first year of service.136 The app offered an alternative entry point into scaled-down social networking using only existing phone contacts to connect users; it was more personalized and lacked the privacy concerns and tracking characteristic of Facebook.

132 Facebook Newsroom, Facebook to Acquire WhatsApp, February 19, 2014, https://newsroom.fb.com/news/2014/02/facebook-to-acquire-whatsapp/. 133 Facebook Newsroom, Facebook to Acquire WhatsApp, February 19, 2014, https://newsroom.fb.com/news/2014/02/facebook-to-acquire-whatsapp/. 134 In a blog post following the 2014 acquisition announcement, founder Jan Koum explained the privacy policy to skeptical consumers as follows. "Respect for your privacy is coded into our DNA, and we built WhatsApp around the goal of knowing as little about you as possible: You don't have to give us your name and we don't ask for your email address. We don't know your birthday. We don't know your home address. We don't know where you work. We don't know your likes, what you search for on the internet or collect your GPS location. None of that data has ever been collected and stored by WhatsApp, and we really have no plans to change that." Jan Koum, Setting the Record Straight, WhatsApp Blog (March 17, 2014) available at https://blog.whatsapp.com/529/Setting-the-recordstraight.

135 Jan Koum, Why We Don't Sell Ads, WhatsApp Blog, June 18, 2012, https://blog.whatsapp.com/?p=245. 136 WhatsApp extended the subscription model across platforms over time. As a result, some early adopters of the service were exempt from charges, others paid \$0.99 for the initial download. Parmy Olson, Exclusive: The RagsTo-Riches Tale Of How Jan Koum Built WhatsApp Into Facebook's New \$19 Billion Baby, Forbes, February 19, 2014, https://www.forbes.com/sites/parmyolson/2014/02/19/exclusive-inside-story-how-jan-koum-built-whatsappinto-facebooks-new-19-billion-baby. Kim-Mai Cutler, The Granddaddy Of Messaging Apps, WhatsApp, Finally Goes For A Subscription Model on iOS, TechCrunch, July 16, 2013, https://techcrunch.com/2013/07/16/whatsappfree/. Venture Capitalist and early WhatsApp investor Jim Goetz of Sequoia Capital observed, "When we first partnered with WhatsApp in January 2011, it had more than a dozen direct competitors, and all were supported by advertising. (In Botswana alone there were 16 social messaging apps). Jan and Brian ignored conventional wisdom. Rather than target users with ads - an approach they had grown to dislike during their time at Yahoo - they chose the opposite tack and charged a dollar for a product that is based on knowing as little about you as possible." Jim Goetz, Four Numbers That Explain Why Facebook Acquired WhatsApp, Sequoia Capital, Feb. 19, 2014, https://sequoiacapital.tumblr.com/post/77211282835/four-numbers-that-explain-why-facebook-acquired 
In February 2014 when Facebook and WhatsApp announced their merger, Facebook served over 1.2 billion monthly active users. Mobile had become an essential component of that usership. More than 75 percent of active users accessed the network through mobile technology and in the fourth quarter of 2013 mobile Facebook users outnumbered those using personal computers for the first time in the company's history.137 Growth in user engagement was increasingly driven by mobile access to the social network and Facebook anticipated that future growth would similarly depend on mobile connections.138 In its 2013 Annual Report Facebook identified mobile applications with competing social features including text messaging, voice, image, and video sharing as a key source of competition for the network. 139

Facebook's reorientation toward mobile-first engagement led the company to develop and release its own standalone messaging app, Facebook Messenger. As mobile users sought short, private, and real-time communication options Facebook identified and acquired one of the bestreceived start-ups in the mobile messaging market, Beluga, and refashioned it into a Facebook product.140 Upon its release in August 2011 Messenger became the number one most-downloaded app on the Apple store overnight.141 Although Messenger quickly claimed the status of the mostutilized iPhone messaging application in the US, Facebook struggled to make headway in markets

${ }_{137}$ SEC Form 10K for the fiscal year ended December 31, 2013, page 15, available at Facebook Investor Relations https://investor.fb.com/financials/?section=annualreports and https://s21.q4cdn.com/399680738/files/doc_financials/annual_reports/FB_AR_33501_FINAL.pdf. 138 SEC Form 10K for the fiscal year ended December 31, 2013, pages 36-40, available at Facebook Investor Relations https://investor.fb.com/financials/?section=annualreports and https://s21.q4cdn.com/399680738/files/doc_financials/annual_reports/FB_AR_33501_FINAL.pdf. 139 SEC Form 10K for the fiscal year ended December 31, 2013, pages 9 and 15, available at Facebook Investor Relations https://investor.fb.com/financials/?section=annualreports and https://s21.q4cdn.com/399680738/files/doc_financials/annual_reports/FB_AR_33501_FINAL.pdf. 140 Jason Kincaid, Facebook Launches Standalone iPhone/Android Messenger App (And It's Beluga), TechCrunch, August 9, 2011, https://techcrunch.com/2011/08/09/facebook-launches-standalone-mobile-messenger-app-andit\%E2\%80\%99s-beluga/. Kim-Mai Cutler, How Beluga Metamorphosed Into Facebook Messenger, AdWeek, Aug. 12, 2011, https://www.adweek.com/digital/facebook-messenger-beluga/.

141 Tim Bradshaw, Facebook Launches Messenger App, Financial Times, August 10, 2011, https://www.ft.com/content/c1975e8a-c372-11e0-b163-00144feabdc0. 
like Europe where early movers had an established advantage and in emerging markets where consumers were more likely to access their networks through feature phones.142 In early 2014, when Facebook and WhatsApp agreed on their merger, Facebook Messenger had 200 million users compared to WhatsApp's 450 million. 143 With the purchase of WhatsApp Facebook would claim ownership of the world's top two messaging companies in terms of market share by user numbers. 144

The $\$ 19$ billion price tag made the WhatsApp acquisition one of the largest mergers in Silicon Valley history.145 Facebook's offer nearly doubled a prior bid from Google to buy the startup for $\$ 10$ billion.146 Moreover, the $\$ 19$ billion deal amounted to approximately one-tenth of Facebook's total market value, while the monetization opportunities associated with WhatsApp

142 According to analytics from spyware app Onovo (a company acquired by Facebook for $\$ 120$ million in October 2013), Facebook's Messenger accounted for 11 percent of monthly active usage on iPhones in the relatively fragmented US messaging market, compared to WhatsApp's penetration at above 80 and 90 percent in several European markets, 71 percent in Brazil, and 34 percent in Russia. Kim-Mai Cutler, The Reality of the Global Messaging App Market: It's Really Freaking Fragmented, TechCrunch Dec. 4, 2012, https://techcrunch.com/2012/12/04/global-messaging-market/. Moreover, users were sending more than twice as many messages per day on WhatsApp compared to Messenger. Charlie Warzel \& Ryan Mac, These Confidential Charts Show Why Facebook Bought WhatsApp, Buzzfeed, December 5, 2018, https://www.buzzfeednews.com/article/charliewarzel/why-facebook-bought-whatsapp. Josh Constine \& Kim-Mai Cutler, Why Facebook Dropped \$19B On WhatsApp: Reach Into Europe, Emerging Markets, TechCrunch, February 19, 2014, https://techcrunch.com/2014/02/19/facebook-whatsapp/. Robinson Meyer, Why Facebook Just Spent \$19 Billion on a Messaging App, The Atlantic, February 19, 2014, https://www.theatlantic.com/technology/archive/2014/02/why-facebook-just-spent-19-billion-on-a-messagingapp/283959/.

143 Jillian D'Onfro, Mark Zuckerberg Says That Facebook Messenger Has 200 Million Monthly Active Users, Business Insider April 23, 2014, https://www.businessinsider.com/facebook-messenger-users-200-million-mau2014-4.

144 Adrian Covert, Facebook Buys WhatsApp for $\$ 19$ Billion, CNN (February 19, 2014) available at https://money.cnn.com/2014/02/19/technology/social/facebook-whatsapp/index.html.

145 Chris O'Brien, Where does WhatsApp acquisition rank in history of tech deals? LA Times, February 20, 2014 https://www.latimes.com/business/technology/la-fi-tn-where-does-whatsapp-rank-in-history-of-tech-deals20140220-story.html. Jim Edwards, WhatsApp is the 2nd-Biggest Tech Acquisition of All Time, Business Insider, February 20, 2014, https://www.businessinsider.com/whatsapp-is-the-2nd-biggest-tech-acquisition-of-all-time-20142. 146 David Gelles, For Facebook, It's Users First and Profits Later, February 20, 2014, https://dealbook.nytimes.com/2014/02/20/for-facebook-its-users-first-and-profits-later/. 
were as yet unproven.147 In 2013, WhatsApp operated at a \$138 million loss.148 WhatsApp’s commitment to maintain privacy precluded merging its users with Facebook's social graph and adding advertising or other monetization options would require a substantial change in WhatsApp's approach to the messaging market. For Facebook, the benefits of owning WhatsApp clearly involved future competitive advantages in messaging and social media. Firstly, the purchase thwarted rival Google's attempt to gain ground as a social network. Secondly, the transition from social sharing on broad networks to one-to-one and group messages promoting private, real-time interactions indicated a significant shift in the social networking services market. Facebook CEO Mark Zuckerberg increasingly alluded to this shift as an important guide for advancing social networking and other social media with his declaration that "the future is private." 149

True to form, the FTC cleared the merger without challenge in April of 2014 with a letter warning both companies about their responsibility to maintain the privacy agreements in place when WhatsApp users accepted the company's terms of service. The letter highlights the distinction between Facebook's data collection and advertising platform model and WhatsApp's

147 David Gelles, Facebook’s \$21.8 Billion WhatsApp Acquisition Lost \$138 Million Last Year, October 28, 2014, https://dealbook.nytimes.com/2014/10/28/facebooks-21-8-billion-acquisition-lost-138-million-last-year/. 148 Kurt Wagner, Facebook Paid \$19 Billion for WhatsApp, Which Lost \$138 Million Last Year, Recode, October 28, 2014, https://www.vox.com/2014/10/28/11632404/facebook-paid-19-billion-for-whatsapp-which-lost-138million-last-year. David Gelles, Facebook’s \$21.8 Billion WhatsApp Acquisition Lost \$138 Million Last Year, October 28, 2014, https://dealbook.nytimes.com/2014/10/28/facebooks-21-8-billion-acquisition-lost-138-millionlast-year/.

149 At Facebook's annual F8 developer conference in 2019, Zuckerberg introduced a new, privacy-focused vision for the entire Facebook platform, stating "The future is private... Over time, I believe that a private social platform will be even more important to our lives than our digital town squares." Nick Statt, Facebook CEO Mark Zuckerberg says the 'future is private', The Verge, April 30, 2019, https://www.theverge.com/2019/4/30/18524188/facebook-f8keynote-mark-zuckerberg-privacy-future-2019. 
promises that it will not collect any personal or contact data from mobile phones or messages, nor send any marketing material without the user's consent. 150

The European Commission also conducted an investigation of the transaction and cleared the deal.151 The EU primarily analyzed the merger within the confines of the relevant market for consumer communications services, not as a potential competition merger. Consumer communication services includes stand-alone apps such as WhatsApp, Viber, Line, WeChat, Facebook Messenger and Skype and those integrated with smartphone hardware or operating systems like Apple's iMessage. In their analysis of consumer communications services, the Commission noted that low switching costs, the tendency for users to multi-home, and the overlap between consumers of the two platforms would undermine any barriers to entry derived from the network effects captured by the merged companies. On these grounds they concluded that the merger would be unlikely to lead to increased concentration in consumer communications services. 152

The Commission ultimately found no competitive concerns in the online advertising services market based on WhatsApp's abstention from advertising and data collection and the number of providers supplying online advertising at the time.153 The EU also analyzed the social networking market and again found no competitive concerns. According to the EU analysis, WhatsApp was not a participant in the social networking market. The Commission considered a social network to involve many functions in addition to communications, including contact lists, user profiles, relationship status, and other social features of online activity. Although the EU

150 April 10, 2014 letter from Jessica L. Rich, Director of the FTC Bureau of Consumer Protection, to Erin Egan, Chief Privacy Officer at Facebook, Inc, and Ann Hoge, General Counsel for WhatsApp Inc, https://www.ftc.gov/system/files/documents/public_statements/297701/140410facebookwhatappltr.pdf. 151 The deal did not meet the EU thresholds but was took up a referral request from Facebook for an Article 4(5) review. Case No COMP/M.7217 - Facebook/WhatsApp. March 10, 2014.

152 Case No COMP/M.7217 - Facebook/WhatsApp. March 10, 2014 at $\S 5.1 .3 .3$, and § 5.1.3.4.

${ }_{153}$ Case No COMP/M.7217 - Facebook/WhatsApp. March 10, 2014 at $§ 4.3 .1$, and § 5.3.1. 
reported that several industry participants informed the Commission that they considered WhatsApp to be a social network already, and predicted that absent the merger WhatsApp would expand and scale in this market, the Commission dismissed these opinions.154 The EU placed considerable weight on statements from WhatsApp management, stating "no indication was found of WhatsApp's plans to become a social network [as defined by the EU] which would compete with Facebook absent the merger."155 In the Commission's view, identifying WhatsApp as a potential competitor in social networking would expand the scope of alternative sources of competition to include other prominent firms in the consumer communications market, including LINE, WeChat, iMessage, Skype, Snapchat, Viber and Hangouts. Such an expansion would only make it less likely that the elimination of a single rival would raise competitive concerns.

Next the Commission evaluated the potential for Facebook to gain market power in social networking by integrating the two platforms. The addition of WhatsApp's consumer base to Facebook's social graph would reinforce the network effects that maintained Facebook's dominance in the market for social networking services. According to the Commission report and later documents, Facebook testified that technical limitations would prevent any such integration without significant user involvement.156 The claims that technical issues prevented integration were proven false when just two years later in 2016 when Facebook began to add WhatsApp user data to the Facebook social graph.157 The EU fined Facebook $€ 110$ million ( $\$ 122$ million) for misleading the Commission but did not reverse their authorization of the acquisition.158

154Case No COMP/M.7217 - Facebook/WhatsApp. March 10, 2014 at II 144.

155 Case No COMP/M.7217 - Facebook/WhatsApp. March 10, 2014 at II 145.

156 Case No COMP/M.7217 - Facebook/WhatsApp. March 10, 2014 at II 138.

157 Amar Toor, Facebook fined $\$ 122$ million by EU for 'misleading information' about WhatsApp acquisition, The Verge, May 18, 2017, https://www.theverge.com/2017/5/18/15657158/facebook-whatsapp-european-commissionfine-data-sharing.

158 European Commission, Mergers: Commission fines Facebook $€ 110$ million for providing misleading information about WhatsApp takeover, May 18, 2017, https://europa.eu/rapid/press-release_IP-17-1369_en.htm. In 2018 WhatsApp Co-founder Brian Acton revealed that Facebook's legal team had coached him to assert that it 
What the EU did not consider was the possibility that the social networking market could be disrupted by a mobile, reliable, private, no frills competitor. While the Commission noted that innovation in communications services was driven by consumer demand for reliability, privacy, and security, and acknowledged that the social networking services and consumer communications services markets exhibited significant overlap, it did not identify the trends in consumer behavior pointing toward the increasing the importance of private, mobile social platforms. Facebook had homed in on the competitive threat that this shift in consumer preferences presented for social networking, especially as it manifested in demographic and geographic groups critical to user growth such as young mobile users and those in emerging markets.

WhatsApp may have posed important potential competition issues. The strength of its reliable private messaging capabilities, its social orientation connecting users through their address books, its access to unique user data, and its ability to scale untethered to a monetization strategy based on consumer surveillance could have raised a threat to Facebook's social network strategy. WhatsApp also may have been able to partner with complementary service providers to generate revenue and develop innovative and competitive social communications products. We will never know. The EU's analysis highlights the problems with the potential competition doctrine. First, the problems of evaluating concentration in the social networking and mobile messaging markets are identical to those pertaining to the acquisition of Instagram: enforcement agencies have yet to identify a workable measure of concentration or a credible data source. The European Commission's report notes the lack of appropriate guidelines despite its own reliance on user

would be difficult to merge the data in advance of his testimony, and that unbeknownst to him there were plans and the means to bridge the data all along. Parmy Olson, Exclusive: WhatsApp Cofounder Brian Acton Gives The Inside Story On \#DeleteFacebook And Why He Left \$850 Million Behind, Forbes, Sep. 26, 2018, https://www.forbes.com/sites/parmyolson/2018/09/26/exclusive-whatsapp-cofounder-brian-acton-gives-the-insidestory-on-deletefacebook-and-why-he-left-850-million-behind/. 
numbers (provided by Facebook) as a proxy for market shares.159 Second, the perceived ease of entry and broad consideration of potential competitors ignores the data barrier that reinforces firm dominance in online platform markets and makes it difficult for the government to isolate the impact of eliminating individual rival companies. Finally, according to the US Merger Guidelines a five percent market share would substantiate the potential for WhatsApp to have significant procompetitive effects in markets for social networking or digital advertising. The EU cites conflicting views on the distinct boundaries of social networking markets, but even if these boundaries were clear, proof of deconcentration still demands appropriate measures of market share and current participation in the market. Harm to potential future competition was alone inadequate to challenge the merger.

The high initial burden on the plaintiff to present a case concerning future conduct and competitive effects serves as a serious deterrent to potential competition mergers, even by dominant firms. Under a simply structural presumption the FTC could have elected to challenge the merger and shifted the burden to Facebook to demonstrate why no harm to future competition could occur, and why, given Facebook's resources it could not internally innovate to achieve its competitive goals. A structural standard of this type should be embraced by critics of agency intervention who believe that the government is poorly positioned to make a strong empirical case, since representatives of the private sector would be the first source of analysis.

159 According to the Commission the Onovo data presented numerous shortcomings and alternative data are not available: "The Commission notes that the market shares indicated above are likely to underestimate the Parties' position, and present some shortcomings. During the market investigation, the Commission attempted to collect additional metrics to measure the competitive importance of players in the market for consumer communications apps. However, no reliable dataset could be produced." Case No COMP/M.7217 - Facebook/WhatsApp. March 10, 2014 at 997. 


\section{REFORM OF THE POTENTIAL COMPETITION DOCTRINE}

The Instagram and WhatsApp examples demonstrate how the potential competition doctrine is designed to fail by placing an unrealistic burden on the government in a challenge to any of the hundreds of mergers by dominant technology firms. We do not think this case is merely the result of new technology that has rendered the law obsolete and unworkable. We argue that the law was made unworkable because of the ideological goals of the Chicago School of economics.

A comparison of the law of horizontal mergers with potential competition mergers is instructive. The Philadelphia National Bank structural presumption remains intact today. The plaintiff, typically the government, bears the initial burden in a $\S 7$ horizontal merger case of demonstrating that the challenged merger should be presumed to substantially harm competition. This is accomplished by showing that the transaction will lead to undue concentration.160 The burden then shifts to the defendant to rebut the presumption. If successful, the burden then shifts back to the Government to present additional evidence of competitive harm. The structural presumption has survived despite erosion by the lower courts. For example, in United States v. Baker Hughes, Inc, 161 Justice Thomas (then on the D.C. Circuit) sought to dilute the presumption stating:

The Supreme Court has adopted a totality-of-the-circumstances approach to the statute, weighing a variety of factors to determine the effects of particular transactions on competition. That the government can establish a prima facie case through evidence on only one factor, market concentration, does not negate the breadth of this analysis. 162

160 United States v. Baker Hughes Inc., 908 F.2d 981, $982-983$ (D.C. Cir. 1990); FTC v. HJ Heinz Co., 246 F. 3d 708, 715 (D.C. Cir. 2001).

161908 F. 2 d 981 (D.C. Cir. 1990)

162908 F. 2d at 984. In a recent article, Carl Shapiro referred to the Baker Hughes departure from the Philadelphia Bank precedent "brazen." Carl Shapiro, "Protecting Competition in the American Economy: Merger Control, Tech Titans, Labor Markets,” 33 J. of Econ Persp. 69, 74 (2019). 
In contrast to the Courts, when the Reagan Administration appointees to the Department of Justice revised the Merger Guidelines in 1982 they replaced the strong structural presumption in the 1968 guidelines with a detailed multi-step effects approach that placed the full burden of demonstrating a merger will harm competition on the government itself. 163 The shift was motivated by the Chicago School supposition that most mergers are efficiency producing, an assumption that was never backed by empirical evidence.164 The higher burden made it much less likely that the Antitrust Agencies would bring a merger challenge, and when they did, defendants could point to any defects in the agency's proof induced by its own standards.165

The shift away from the Philadelphia Bank structural presumption for mergers that impact potential competition came earlier. It was achieved in complete form in Justice Powell's opinion in United States v. Marine Bancorporation.166 This wrong turn in 1974 must be corrected in order for the potential competition doctrine to have any practical application in tech markets. A starting point for such a correction would be to resurrect the pre-Marine Bancorporation 1968 Merger Guidelines. Under the 1968 Merger Guidelines, a merger would be likely to be challenged when a firm with a large market share (above $25 \%$ ) purchases a firm that is "one of the most likely entrants into the market."167 The determination of whether a firm is a likely entrant is based on the capacity

163 Sandeep Vaheesan, The Profound Nonsense of consumer Welfare Antitrust, Antitrust Bulletin, Forthcoming. 164 John Kwoka, The Structural Presumption and the Safe Harbor in Merger Review: False Positives or Unwarranted Concerns? 81 Antitrust L. J. 837 (2017); John Kwoka, Mergers, Merger control, and Remedies: A Retrospective Analysis of U.S. Policy, MIT Press (2015). 165908 F.2d 985.

166 Whether this was Judge Powell's first attempt at an application of the Chicago School's skepticism regarding merger regulation cannot be determined. Three years prior to authoring his opinion in United States v. Marine Bancorporation, Justice Powell, then an influential corporate attorney, wrote his famous 1971 memo to the U.S. Chamber of Commerce titled "Attack on American Free Enterprise System." The Powell memo "is widely cited as the beginning of the corporate mobilization to transform American law and politics." 166 The Powell memo inspired business support of free market ideas and skepticism about business regulation through funding of several major conservative think tanks including The Business Roundtable, founded in 1972, and The Heritage Foundation, established in 1973. Following the Marine Bancorporation opinion Justice Powell is credited with authorship of the first major antitrust opinion openly applying Chicago School economics in 1977, Continental T.V., Inc. v. GTE Sylvania Inc. 1671968 Merger Guidelines at $\S 18$. 
of the firm to enter, an incentive to enter based on attractiveness or a special relationship of the market and potential profitability of entry, or a manifested interest in entry. While a possible starting point, a further correction is required. The 1968 Guidelines analysis of entry is open ended and not sufficiently amenable to a tractable structural presumption that could be used by the Courts.

What is needed to address the intractability of proof in a potential competition merger is a reasonable proxy that can incorporate a structural presumption for the likely entry or entry advantage of the start-up. Joe Brodley referred to such a proxy as a "legal surrogate to identify the entry advantage of the acquiring firm."168 Brodley recommends the use of the concept of "proximate markets" to provide the structural presumption of ability to enter and entry advantage for a target firm. As Brodley explains:

Market proximity is a concept of presumptive entry advantage. Two markets are proximate to the extent that a knowledgeable firm in one market possesses the necessary production and marketing information and other capabilities to operate in the other. Market proximity provides a suitable surrogate for entry advantage because, other factors being equal, there is less risk and therefore less expense involved in entering a familiar market. 169

To establish proximity Brodley focused on the factors that would be critical to the entry analysis of a business: production, marketing, technology and customer relations similarities. 170 More pointed criteria can be defined given the accumulated knowledge concerning tech industry mergers. For example, proximity to the general search market in which Google is dominant would include such factors as specialized search features, search advertising abilities, and the overlap of users with Google properties. The criteria would capture a vertical shopping site that is supported by search advertising and would clearly be a proximate market to the general search market. There are many such vertical markets that are potential rivals to Google's general search advertising

168 Joseph Brodley, Potential Competition under the Merger Guidelines, 71 Calif. L. Rev. 376, 391 (1983).

$169 I d$.

$170 I d$. at 392. 
revenues. Proximate markets to the social networking market certainly would include markets that compete with the functions hosted by Facebook's social network for user engagement and/or compete for similar targeted advertising dollars. In addition, the ability to gather user data complementary to Facebook's may be an indicia of proximity.

Under our approach both the Instagram and the WhatsApp mergers would have been challenged. Instagram operated in a proximate market. In the months before the Instagram acquisition, Facebook identified photo sharing as a key component of social network functionality, particularly on the mobile platform, and a key facet of Facebook's own success.171 The social features common to Facebook and Instagram demonstrate considerable proximity between the two companies. The private messaging offered by WhatsApp was rapidly becoming a prevailing aspect of online communication for individuals and groups, with networks established via the user's own address book posing an alternative to the public platform approach. In both cases, users' increasing reliance on mobile technology for digital interactions forced a collision between Facebook and the proximate markets that provided the aspects of online interaction its users increasingly demanded. Under the structural approach, tech mergers like Facebook's acquisitions of Instagram and WhatsApp could be challenged and receive the scrutiny they deserve. Regardless of the particular cases engaged the process would develop a new guide to judicial decision making in tech markets.

We advocate the informed development of a fully structural presumption for potential competition mergers in technology markets. We think that this is how the law of potential competition mergers should have developed after the Philadelphia Bank case, had it not been derailed by United States v. Marine Bancorporation.

171 MG Siegler, Zuckerberg: Facebook Photos Used 5 Or 6 Times More Than Competitors - Combined, TechCrunch, Aug. 08, 2010, https://techcrunch.com/2010/08/27/facebook-photos-usage/. 


\section{CONCLUSION}

Big Tech has demonstrated that it has an insatiable appetite for acquisitions of small startups. The sheer number of acquisitions should raise red flags for the antitrust agencies. After many hundreds of such acquisitions, so few challenges or requests to fully investigate these acquisitions demands some explanation. We argue that one aspect of the problem is that the law of potential competition has developed in a manner that essentially ties the hands of the antitrust agencies because it demands levels of proof that are intractable, particularly for a court.

We have arrived at this point because of the widespread acceptance of the Chicago School's approach to mergers. The Chicago School asserted that only mergers to monopoly were a legitimate antitrust concern, and that mergers that do not result in monopoly are usually efficiency increasing and undertaken for that purpose. 172 With these background presumptions, the Chicago School advocates jettisoned the structural approach to mergers and replaced it with an effects analysis that raised the burden to merger challenges and provided defense counsel with multiple avenues to attack a government challenge.

The efficacy of the potential competition doctrine fell to the same unsound premises beginning in 1974 in United States v. Bancorporation. The doctrine now embraces difficult tests of conduct and performance. In markets where tipping occurs, technology is rapidly changing, and start-up firms can scale and challenge dominant incumbents, a viable potential competition law is critical to protect competition and consumers. What is needed is to untie the hands of government antitrust enforcers by articulating a clear structural test to identify acquisitions of potential competition. To achieve this standard we contend that very little innovation in law or in economics

172 Frank Easterbrook, Limits of Antitrust, 63 Tex. L. Rev. 1, 3 (1984); Robert Bork, The Antitrust Paradox: A Policy at War with Itself, Basic Books (1978) at 221. 
is necessary. We need only reverse the damage brought by the Chicago School and its neoliberal revolution and return to the potential competition doctrine of the 1968 Merger Guidelines. 


\section{Appendix}

\begin{tabular}{|c|c|c|c|c|c|}
\hline \multicolumn{6}{|c|}{ Facebook's Completed Acquisitions } \\
\hline $\begin{array}{l}\text { Announce } \\
\text { Date }\end{array}$ & $\begin{array}{l}\text { Effective } \\
\text { Date }\end{array}$ & Price (USD) & Company & $\begin{array}{l}\text { Year } \\
\text { Founded }\end{array}$ & $\begin{array}{l}\text { Primary } \\
\text { Market }\end{array}$ \\
\hline $7 / 19 / 2007$ & $7 / 19 / 2007$ & undisclosed & Parakey & 2005 & Platform \\
\hline $6 / 23 / 2008$ & $6 / 23 / 2008$ & $\$ 31$ million $^{\mathrm{d}}$ & Connect U & 2004 & $\begin{array}{l}\text { Social } \\
\text { Networking }\end{array}$ \\
\hline $8 / 10 / 2009$ & $8 / 10 / 2008$ & $\$ 47.5$ million $^{\mathrm{d}}$ & Friend Feed & 2007 & $\begin{array}{l}\text { Social } \\
\text { Networking }\end{array}$ \\
\hline $2 / 1 / 2010$ & $2 / 19 / 2010$ & undisclosed & Octazen & 2006 & $\begin{array}{l}\text { Data \& } \\
\text { Analytics }\end{array}$ \\
\hline $4 / 3 / 2010$ & $3 / 2 / 2010$ & undisclosed & Divvyshot & 2009 & Media sharing \\
\hline $5 / 13 / 2010$ & $5 / 13 / 2010$ & $40000000^{\mathrm{d}}$ & Friendster (patents) & 2001 & $\begin{array}{l}\text { Social } \\
\text { Networking }\end{array}$ \\
\hline $5 / 26 / 2010$ & $5 / 26 / 2010$ & undisclosed & ShareGrove & 2008 & Messaging \\
\hline $7 / 8 / 2010$ & $7 / 8 / 2010$ & $\$ 2.5$ million $^{\mathrm{c}}$ & Nextstop & 2009 & $\begin{array}{l}\text { Location } \\
\text { services }\end{array}$ \\
\hline $8 / 15 / 2010$ & $8 / 15 / 2010$ & $\$ 10$ million $^{\mathrm{bc}}$ & Chai Labs & 2007 & $\begin{array}{l}\text { Location } \\
\text { services }\end{array}$ \\
\hline $8 / 20 / 2010$ & $8 / 20 / 2010$ & $\$ 10$ million $^{\mathrm{c}}$ & Hot Potato & 2009 & $\begin{array}{l}\text { Location } \\
\text { services }\end{array}$ \\
\hline $10 / 29 / 2010$ & $10 / 29 / 2010$ & $\$ 10$ million $^{\mathrm{d}}$ & Drop.io & 2007 & Media sharing \\
\hline $11 / 16 / 2010$ & $11 / 16 / 2010$ & undisclosed & Walletin & 2010 & Gaming \\
\hline $11 / 16 / 2010$ & $11 / 16 / 2010$ & undisclosed & Zenbe & 2006 & Messaging \\
\hline $1 / 25 / 2011$ & $1 / 25 / 2011$ & undisclosed & Rel8tion & 2010 & Advertising \\
\hline $3 / 1 / 2011$ & $3 / 2 / 2011$ & undisclosed & Beluga & 2010 & Messaging \\
\hline $3 / 20 / 2011$ & $3 / 20 / 2011$ & $\$ 70$ million $^{\text {bc }}$ & Snaptu & 2007 & Platform \\
\hline $3 / 24 / 2011$ & $3 / 24 / 2011$ & undisclosed & Recrec & 2010 & Platform \\
\hline $4 / 27 / 2011$ & $4 / 27 / 2011$ & undisclosed & Datum & 2011 & $\begin{array}{l}\text { Data \& } \\
\text { Analytics }\end{array}$ \\
\hline $6 / 9 / 2011$ & $6 / 9 / 2011$ & undisclosed & Sofa & 2006 & Design \\
\hline $8 / 2 / 2011$ & $8 / 2 / 2011$ & undisclosed & Push Pop Press & 2010 & E-Publishing \\
\hline $10 / 11 / 2011$ & $10 / 10 / 2011$ & undisclosed & Friend.ly & 2010 & $\begin{array}{l}\text { Data \& } \\
\text { Analytics }\end{array}$ \\
\hline $11 / 8 / 2011$ & $11 / 8 / 2011$ & undisclosed & Strobe & 2011 & $\begin{array}{l}\text { Developer } \\
\text { Tools }\end{array}$ \\
\hline $11 / 8 / 2011$ & & undisclosed & Digital Staircase & 2008 & Media sharing \\
\hline $11 / 15 / 2011$ & $11 / 15 / 2011$ & undisclosed & MailRank & 2010 & Messaging \\
\hline $11 / 23 / 2011$ & & undisclosed & WhoGlue & 2000 & Messaging \\
\hline $12 / 2 / 2011$ & $12 / 2 / 2011$ & $3000000^{c}$ & Gowalla & 2007 & $\begin{array}{l}\text { Location } \\
\text { services } \\
\end{array}$ \\
\hline $2 / 12 / 2012$ & $2 / 12 / 2012$ & undisclosed & Caffeinated Mind & 2010 & Media sharing \\
\hline $3 / 8 / 2012$ & & undisclosed & Gazehawk & 2009 & $\begin{array}{l}\text { Data \& } \\
\text { Analytics }\end{array}$ \\
\hline
\end{tabular}




\begin{tabular}{|c|c|c|c|c|c|}
\hline \multicolumn{6}{|c|}{ Facebook's Completed Acquisitions } \\
\hline $\begin{array}{l}\text { Announce } \\
\text { Date }\end{array}$ & $\begin{array}{l}\text { Effective } \\
\text { Date }\end{array}$ & Price (USD) & Company & $\begin{array}{l}\text { Year } \\
\text { Founded }\end{array}$ & $\begin{array}{l}\text { Primary } \\
\text { Market }\end{array}$ \\
\hline $4 / 9 / 2012$ & $9 / 6 / 2012$ & \$1 billion ${ }^{\mathrm{a}}$ & Instagram & 2010 & Media sharing \\
\hline $4 / 13 / 2012$ & $4 / 13 / 2012$ & undisclosed & $\begin{array}{l}\text { Malbec Labs, } \\
\text { Inc/Tagtile }\end{array}$ & 2011 & E-commerce \\
\hline $4 / 23 / 2012$ & $6 / 14 / 2012$ & $\$ 550$ million $^{\mathrm{a}}$ & $\begin{array}{l}\text { AOL Patents via } \\
\text { Microsoft }\end{array}$ & & Platform \\
\hline $5 / 8 / 2012$ & & undisclosed & Glancee & 2010 & $\begin{array}{l}\text { Location } \\
\text { services }\end{array}$ \\
\hline $5 / 15 / 2012$ & $5 / 15 / 2012$ & undisclosed & Lightbox.com & 2010 & Media sharing \\
\hline $5 / 18 / 2012$ & & $\$ 80$ million $^{\mathrm{d}}$ & Karma & 2011 & E-commerce \\
\hline $5 / 24 / 2012$ & $5 / 24 / 2012$ & undisclosed & Bolt | Peters & 2002 & $\begin{array}{l}\text { Data \& } \\
\text { Analytics }\end{array}$ \\
\hline $6 / 12 / 2012$ & & undisclosed & Peiceable & 2010 & $\begin{array}{l}\text { Developer } \\
\text { Tools }\end{array}$ \\
\hline $6 / 18 / 2012$ & & $\$ 100$ million $^{\mathrm{b}}$ & Face.com & 2005 & $\begin{array}{l}\text { Developer } \\
\text { Tools }\end{array}$ \\
\hline $7 / 14 / 2012$ & & undisclosed & Spool / Blueprint Labs & 2010 & media sharing \\
\hline $7 / 20 / 2012$ & $7 / 20 / 2012$ & undisclosed & Acrylic Software & 2008 & Design \\
\hline $8 / 24 / 2012$ & & undisclosed & Threadsy & 2008 & $\begin{array}{l}\text { Data \& } \\
\text { Analytics }\end{array}$ \\
\hline $3 / 1 / 2013$ & $4 / 26 / 2013$ & $\begin{array}{l}\$ 50-\$ 100 \\
\text { million }^{\mathrm{d}}\end{array}$ & Atlas Advertiser Suite & 2001 & Advertising \\
\hline $3 / 8 / 2013$ & & undisclosed & Mixtent/Storylane & 2010 & $\begin{array}{l}\text { Social } \\
\text { Networking }\end{array}$ \\
\hline $3 / 14 / 2013$ & & undisclosed & Hot Studio & 1997 & Design \\
\hline 11-Apr-13 & & undisclosed & Osmeta & 2011 & $\begin{array}{l}\text { Developer } \\
\text { Tools }\end{array}$ \\
\hline $4 / 23 / 2013$ & & undisclosed & Spaceport.io & 2007 & $\begin{array}{l}\text { Developer } \\
\text { Tools }\end{array}$ \\
\hline $4 / 25 / 2013$ & $5 / 23 / 2013$ & $\$ 85$ million $^{\mathrm{bc}}$ & Parse & 2011 & $\begin{array}{l}\text { Developer } \\
\text { Tools }\end{array}$ \\
\hline $7 / 18 / 2013$ & & undisclosed & Monoidics & 2009 & $\begin{array}{l}\text { Developer } \\
\text { Tools }\end{array}$ \\
\hline $8 / 12 / 2013$ & $9 / 25 / 2013$ & undisclosed & $\begin{array}{l}\text { Mobile Technologies | } \\
\text { Jibbigo }\end{array}$ & 2001 & $\begin{array}{l}\text { Artificial } \\
\text { Intelligence }\end{array}$ \\
\hline $8 / 23 / 2013$ & & undisclosed & Midnox | Luma & 2011 & Media sharing \\
\hline $10 / 14 / 2013$ & & $\$ 200$ million $^{\mathrm{b}}$ & Onovo & 2010 & $\begin{array}{l}\text { Data \& } \\
\text { Analytics }\end{array}$ \\
\hline $12 / 17 / 2013$ & & undisclosed & Sportstream & 2012 & $\begin{array}{l}\text { Social } \\
\text { Networking }\end{array}$ \\
\hline $1 / 8 / 2014$ & & $\$ 15$ million $^{\mathrm{b}}$ & Little Eye Labs & 2012 & $\begin{array}{l}\text { Developer } \\
\text { Tools }\end{array}$ \\
\hline $1 / 13 / 2014$ & & $\$ 15$ million $^{\mathrm{b}}$ & Branch Media & 2011 & Messaging \\
\hline $2 / 19 / 2014$ & $10 / 3 / 2014$ & $\$ 19$ billion $^{\mathrm{a}}$ & WhatsApp & 2009 & Messaging \\
\hline $3 / 25 / 2014$ & & $\$ 3$ billion $^{\mathrm{d}}$ & Oculus & 2012 & Virtual Reality \\
\hline
\end{tabular}




\begin{tabular}{|c|c|c|c|c|c|}
\hline \multicolumn{6}{|c|}{ Facebook's Completed Acquisitions } \\
\hline $\begin{array}{l}\text { Announce } \\
\text { Date }\end{array}$ & $\begin{array}{l}\text { Effective } \\
\text { Date }\end{array}$ & Price (USD) & Company & $\begin{array}{l}\text { Year } \\
\text { Founded }\end{array}$ & $\begin{array}{l}\text { Primary } \\
\text { Market }\end{array}$ \\
\hline $3 / 28 / 2014$ & & $\$ 20$ million $^{c}$ & Ascenta & 2010 & Hardware \\
\hline $4 / 24 / 2014$ & & undisclosed & ProtoGeo Oy | Moves & 2012 & $\begin{array}{l}\text { Data \& } \\
\text { Analytics }\end{array}$ \\
\hline 3-Jun-14 & & undisclosed & Pryte & 2010 & Platform \\
\hline $6 / 24 / 2014$ & & undisclosed & Carbon Design Group & 1993 & Hardware \\
\hline $7 / 2 / 2014$ & $8 / 14 / 2014$ & $\$ 500$ million $^{\mathrm{bc}}$ & LiveRail & 2007 & Advertising \\
\hline $7 / 7 / 2014$ & & undisclosed & RakNet & 2001 & $\begin{array}{l}\text { Developer } \\
\text { Tools }\end{array}$ \\
\hline $8 / 8 / 2014$ & & undisclosed & PrivateCore & 2011 & Platform \\
\hline 14-Dec-14 & & undisclosed & Nimble VR & 2012 & Virtual Reality \\
\hline $12 / 16 / 2014$ & & undisclosed & 13th Lab & 2010 & Virtual Reality \\
\hline $1 / 6 / 2015$ & & undisclosed & Wit.ai & 2013 & $\begin{array}{l}\text { Developer } \\
\text { Tools }\end{array}$ \\
\hline $1 / 8 / 2015$ & & undisclosed & QuickFire Networks & 2012 & Media Sharing \\
\hline $3 / 13 / 2015$ & & undisclosed & The Find & 2004 & E-commerce \\
\hline $5 / 19 / 2015$ & & undisclosed & TugBoat Yards & 2012 & E-commerce \\
\hline 26-May-15 & & undisclosed & Surreal Vision & 2014 & Virtual Reality \\
\hline $7 / 16 / 2015$ & & $\$ 60$ million $^{\mathrm{bc}}$ & Pebbles Interfaces & 2010 & Virtual Reality \\
\hline $10 / 3 / 2015$ & & undisclosed & Engada & 2014 & $\begin{array}{l}\text { Emerging } \\
\text { markets }\end{array}$ \\
\hline $3 / 9 / 2016$ & & $\$ 150$ million $^{\mathrm{d}}$ & Masquerade & 2015 & Media Sharing \\
\hline $5 / 23 / 2016$ & & undisclosed & Two Big Ears & 2013 & Virtual Reality \\
\hline $8 / 8 / 2016$ & & undisclosed & Eyegroove & 2013 & Media Sharing \\
\hline 9/19/2016 & $9 / 20 / 2016$ & undisclosed & Nascent Objects Inc & 2014 & Hardware \\
\hline $10 / 13 / 2016$ & & undisclosed & InfiniLED & 2010 & Hardware \\
\hline $11 / 11 / 2016$ & & undisclosed & Crowd Tangle & 2012 & $\begin{array}{l}\text { Data \& } \\
\text { Analytics }\end{array}$ \\
\hline $11 / 11 / 2016$ & & undisclosed & Zurich Eye & 2015 & Hardware \\
\hline $11 / 16 / 2016$ & & undisclosed & Faciometrics & 2015 & Media Sharing \\
\hline $12 / 29 / 2016$ & & undisclosed & The Eye Tribe & 2011 & Virtual Reality \\
\hline $7 / 24 / 2017$ & & undisclosed & Source3 Inc & 2014 & Platform \\
\hline $7 / 31 / 2017$ & & undisclosed & Ozlo & 2013 & $\begin{array}{l}\text { Artificial } \\
\text { Intelligence }\end{array}$ \\
\hline $8 / 11 / 2017$ & & undisclosed & Fayteq AG & 2011 & Media Sharing \\
\hline $10 / 16 / 2017$ & & $\$ 100$ million $^{\mathrm{d}}$ & Midnight Labs | tbh & 2013 & $\begin{array}{l}\text { Social } \\
\text { Networking }\end{array}$ \\
\hline $1 / 23 / 2018$ & & undisclosed & confirm.io & 2015 & Platform \\
\hline $7 / 2 / 2018$ & & $\$ 30$ million $^{\mathrm{b}}$ & Bloomsbury AI & 2015 & $\begin{array}{l}\text { Artificial } \\
\text { Intelligence }\end{array}$ \\
\hline 26-Jul-18 & & $\$ 100$ million $^{\mathrm{b}}$ & Redkix & 2014 & Platform \\
\hline $8 / 13 / 2018$ & & undisclosed & Vidpresso & 2012 & Media Sharing \\
\hline
\end{tabular}




\begin{tabular}{|l|l|l|l|l|l|}
\hline \multicolumn{7}{|c|}{ Facebook's Completed Acquisitions } \\
\hline $\begin{array}{l}\text { Announce } \\
\text { Date }\end{array}$ & $\begin{array}{l}\text { Effective } \\
\text { Date }\end{array}$ & Price (USD) & Company & $\begin{array}{l}\text { Year } \\
\text { Founded }\end{array}$ & $\begin{array}{l}\text { Primary } \\
\text { Market }\end{array}$ \\
\hline $2 / 4 / 2019$ & & undisclosed & Chain Space & 2018 & $\begin{array}{l}\text { Digital } \\
\text { Currency }\end{array}$ \\
\hline $2 / 8 / 2019$ & undisclosed & Grokstyle & 2016 & $\begin{array}{l}\text { Artificial } \\
\text { Intelligence }\end{array}$ \\
\hline a Terms reported by transacting parties & \\
\hline b Terms reported in Thomson Reuters M\&A Database \\
\hline c Terms reported in Crunchbase Pro \\
\hline d Terms reported by media coverage of the transaction. Contact authors for citations. \\
\hline
\end{tabular}

